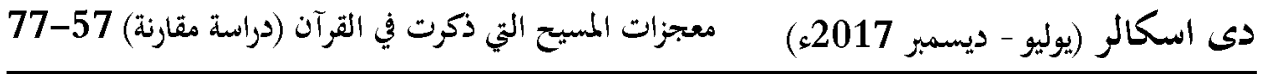

$$
\begin{aligned}
& \text { معجزات المسيح التي ذكرت في القرآن ولم تذكر في الإنجيل } \\
& \text { دراسة مقارنة بين آراء علماء المسلمين والنصارى }
\end{aligned}
$$

\title{
ARABIC -MIRACLES OF JESUS CHRIST WHICH ARE ONLY DESCRIBED IN THE QŪRĀN BUT DO NOT MENTIONED IN THE BIBLE: A COMPARATIVE STUDY
}

\author{
Riaz Ahmad Saeed*, Dr. Mati ur Rehman** \\ The Scholar Islamic Academic Research Journal || Web: www.siarj.com || \\ P. ISSN: 2413-7480 || Vol. 3, No. 2 || June-December 2017 || P. 57-77 \\ DOI: 10.29370/siarj/issue5ar11 \\ URL: https://doi.org/10.29370/siarj/issue5ar11 \\ License: Copyright c 2017 NC-SA 4.0
}

\begin{abstract}
:
The miracles are one of the most significant studies of the Holy Qürān and the Holy Bible. The Muslim and Christian scholars both are agreed about the meanings of miracles but differ in number, nature, and sources. The objectives of the miracles are to help out the Messengers for preaching and establishing reason on public. The Muslims and Christians both have strong faith on the Christ's miracles in the Qürān and the Bible. The Muslims understand these miracles as the sign of dignity and respect of Jesus Christ from Allah, but the Christians claim them as the sign of Godship of Christ, which is not true interpretation. Many verses of the Qürān

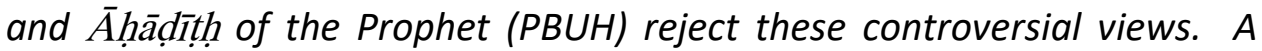
variety of Christ's miracles are described in Quran and Bible in various contexts but some of them are described only in the Quran and do not mentioned in Bible; For example: 1- speaking of Christ in the Cot, 2- To save the Jesus from Jews, 3-The food comes down from heaven, 4-Jesus

*Lecturer, $N$ ational U niversityof M odern Languages Email:riazussaeed@ gmail.com ** A ssistant Professor, I slamabad M odel C ollege for B oys G - 11/1 I slamabad, Email: muti.iiui@gmail.com
\end{abstract}


دي اسكالر (يوليو - ديسمبر 2017ء) معجزات المسيح التي ذكرت في القرآن (دراسة مقارنة) 57-77

Christ makes birds from mud and 5-News about food eating. Muslims and Christians scholars differ about these miracles which are only mention in the Quran or the Bible. Muslim scholars accept the Christ's miracles of Quran and also in the Bible but according to Christian scholars' views these miracles are not acceptable because they are taken from unauthentic, agnostic and apocryphal Christian sources of Christianity. This important study deals with the miracles of Jesus Christ which are only described in the Quran but do not mentioned in the Bible in the light of Muslim-Christian's scholarly views.

KEYWORDS: Christ miracles, Qūrān and Bible, Muslim-Christian views.

الكلمات المفتاحية: معجزة خالدة، عدالة نزيهة، بلاغة وعلاجية، علوم قرآنية ، الإمام زكشي.

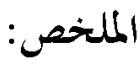

أراد الله أن يقيم الحجة على عباده، أرسل إليهم الرسل الكرام لإصلاحهم وبتحديد الشريعة.

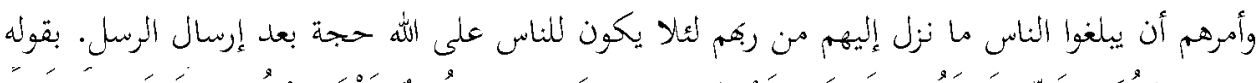

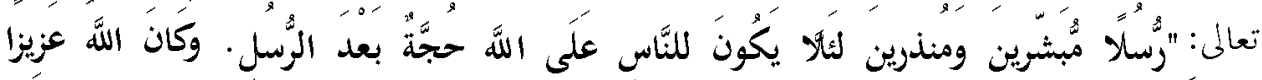

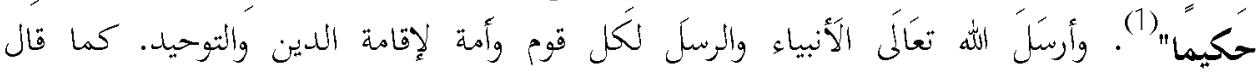

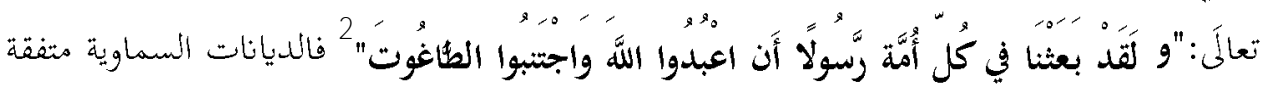

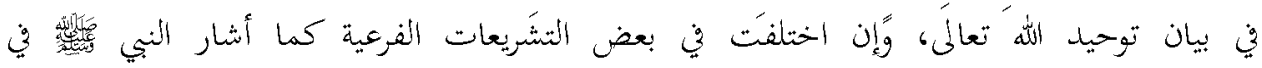
قوله:"الأنبياء إخوة ودينهم واحد". ${ }^{3}$ و ما بعث اللهرسولا إلا أيله بالكتب، والصحف، والآيات، والبراهين، والمعجزات على صدق رسالته وصحة دعواه ولإحقاق الحقة، وإبطال الباطل، ونصرة الرسول.

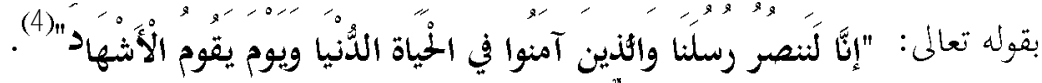

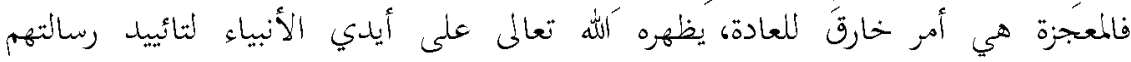

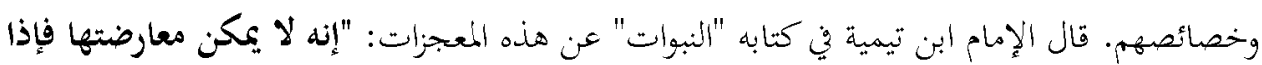

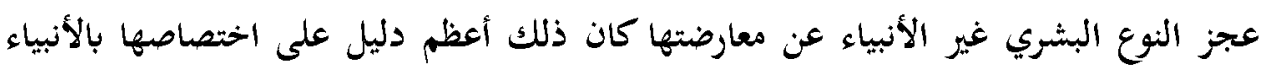
بخلاف ما كان موجودا بغيرها. فهذا لا يكون آية البتة،فأصل هذا أن يعرف وجود الأنبياء في العالم

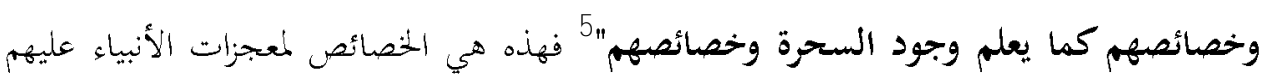

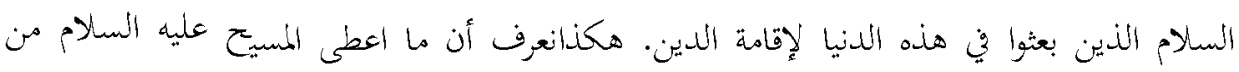

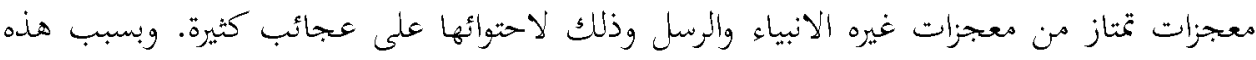

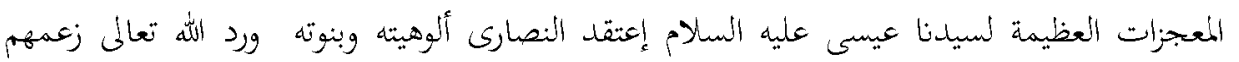




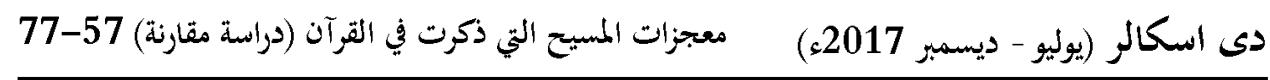

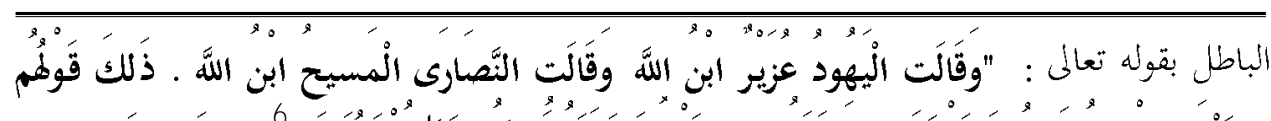

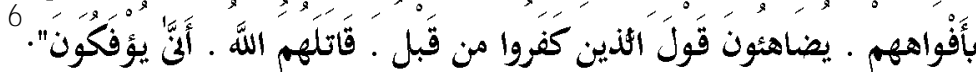

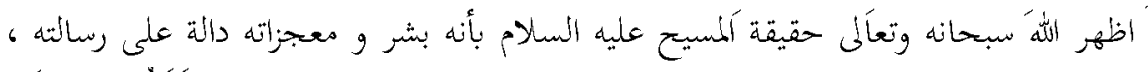

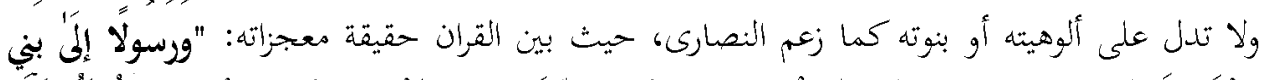

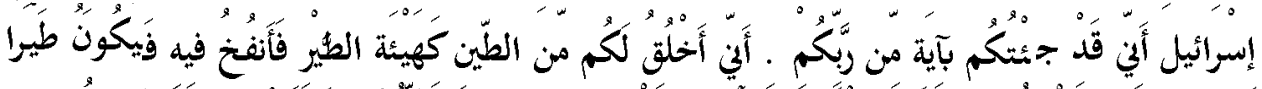

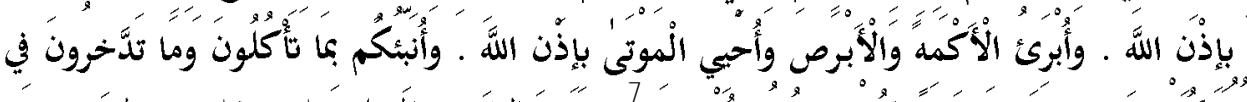

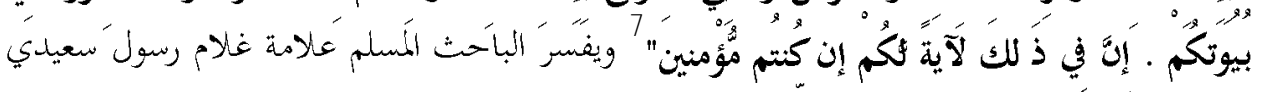

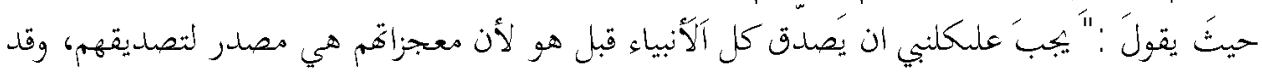

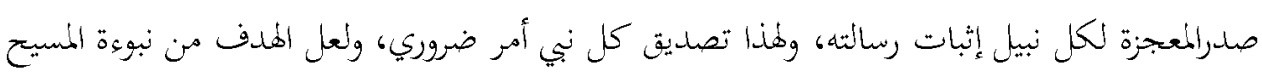

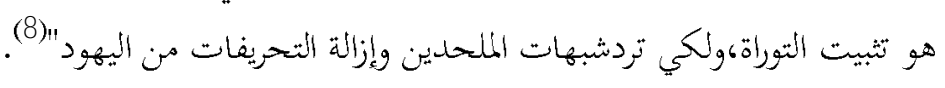

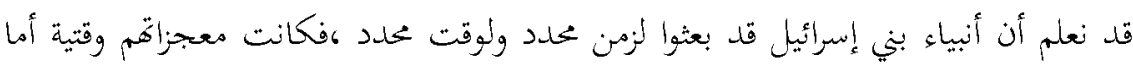

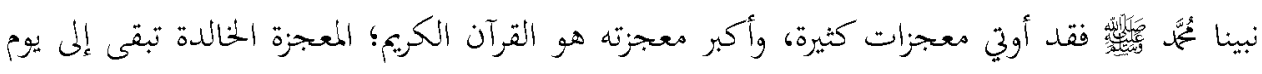

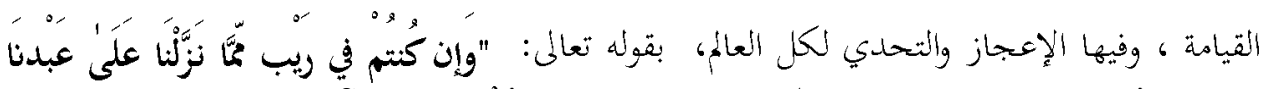

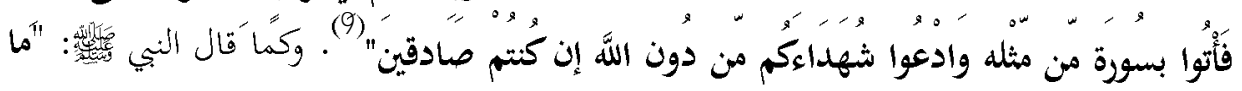

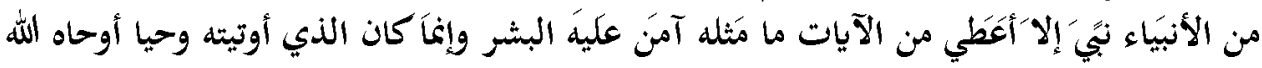

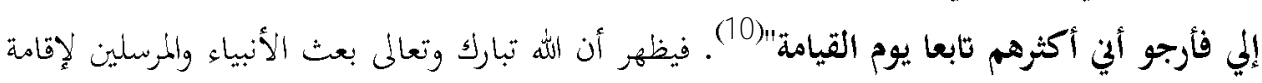

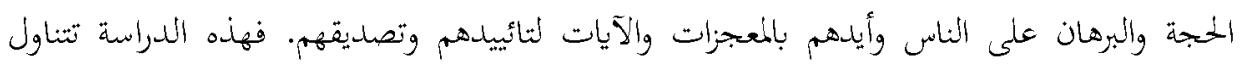

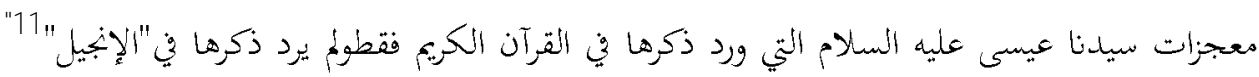
في ضوء آراء علماء المسلمين والمسيحيين. مفهوم المعجزة في الإسلام

المعجزة في الإسلام ها أمور كثيرة، وهي أمر خارق" للعادة، يظهره الله تعالى على أيدي الأنبياء

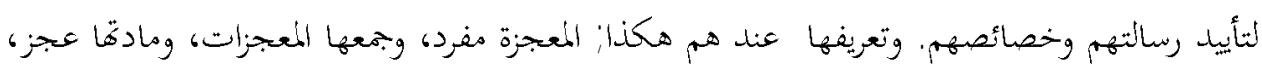

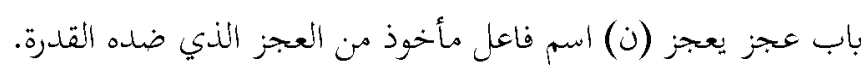
قال ابن منظور في لسان العرب: العجز نقيض الحزم ويقال: أعجزت فلانان إذا ألفيته عاجزا، العزاه

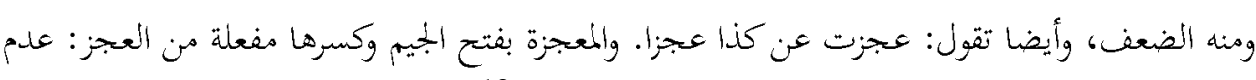

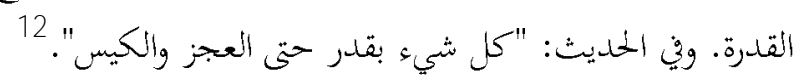
وقال الزبيدي في تاج العوسي: "اعجزه: صيره عاجزاً أي عن إدراكه واللحوق به...ومعجزة 
قال الإمام راغب الأصفهاني في المفردات:العجز أصله التأخر عن الشيء وهو له عند عجزة

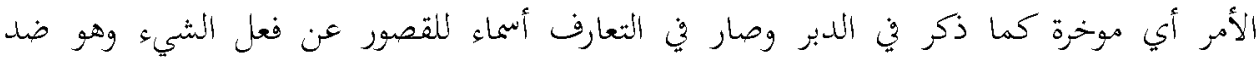

قال ابن تيمية:"ان كل مايخرج عن الأمر المعتاد فإنه معجزة وهو خارق للعادة إذا اقترن

$$
\text { بلدوى النبوة". }
$$

وعرفها الإمام الجرجاني: " أمر خارق للعادة داع للخير والسعادة مقرون بدعوى النبوة قصد به

$$
\text { إظهار صدق من إدعى أنه رسول من الله". } 16
$$

وقال سيف الدين الآمدي:"المعجزة هي كل ما قصد بها إظهار صدق المتحدي بالنبوة الملدعي

$$
17 \text { الرسالة" }
$$

وعرفها الشيخ الزرقاني: "المعجزة هي أمر خارق للعادة خارج عن حدود الأسباب المعروفة

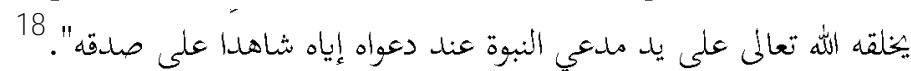

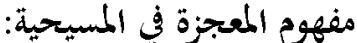

المسيحية تعتقد على المعجزات ، وتعتبرها من أصول الإيعان وعقيدتها واهتم العلماء الممسيحية

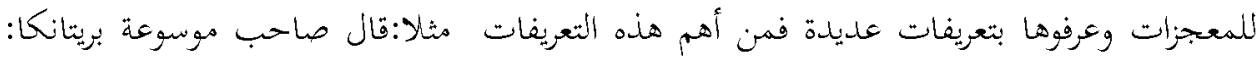
"المعجزة حادثة خارق للعادة تنسب إلى حضور فعل فوق الطبيعة أو قوة إلهية". 19 وعرف صاحب موسوعة كاثوليكية الجديدة: "استخدم المعجزة اللاهوتية، إستثائي محسوسة إلى الحواس التي ينتجها الله في السياق الديني، كدليل خارق غيرعادي وفي تفسير عبارة حدث غير عادي في الله التي ينتجها الله في سياق ديني كدليل الخارق للعادة". 20

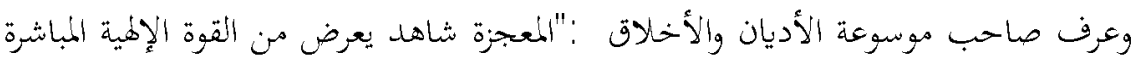

$$
\text { في فعل واضح خارق للعادة ويفيد الدلالة على خيرية الإله. }
$$

وقال القس طالب الدين عن تعريف المعجزة:عند مذهب المسبيحي المعجزة: "أمر خارق للعادة التي ظهرت على الأرض لثبوت نبوة الرمول وفي اللغة المعجزة أمر عاجز وهو الفصل الني يشاهد الإنسان خلاف الفطرة هو الآن عاجز وقائل للقدرة غير مرئية التي لا يجربه في معمول 22 الفطرة

والذي أراه من خلال هذه التعريفاتأن تعريف القس طالب الدين من أشمل التعريف حيث

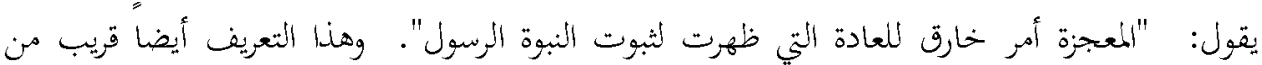




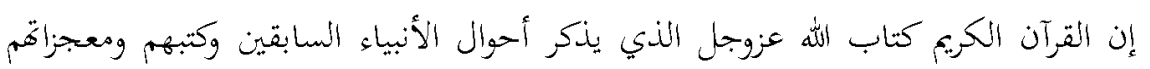

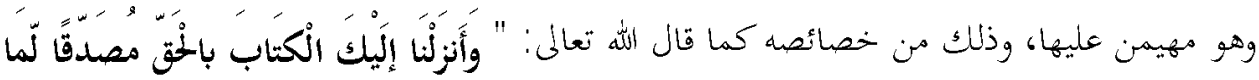

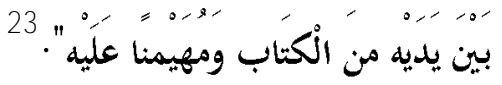

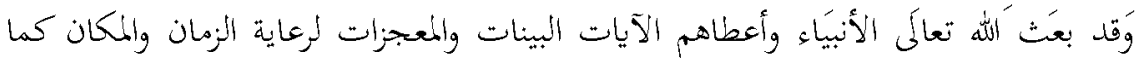

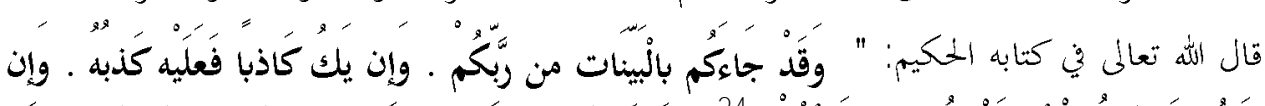

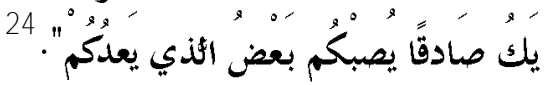

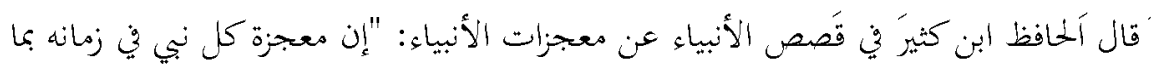

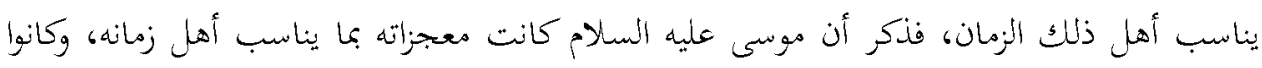

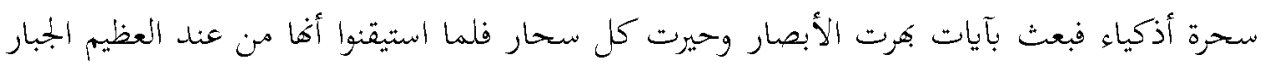

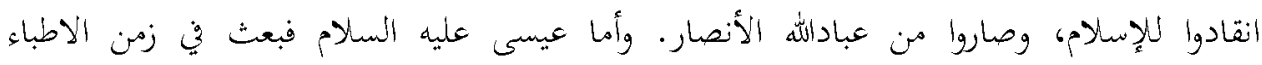

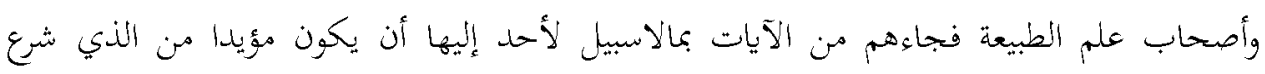

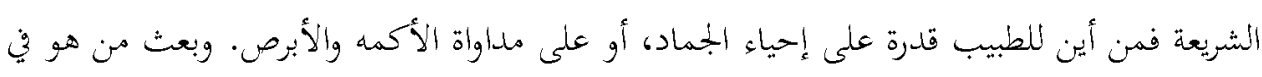

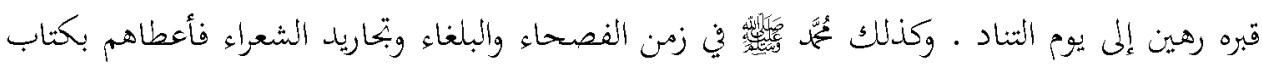

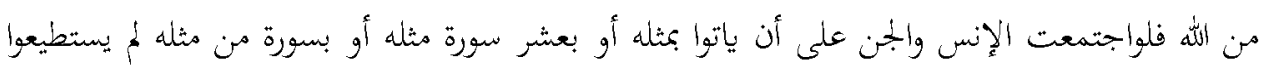

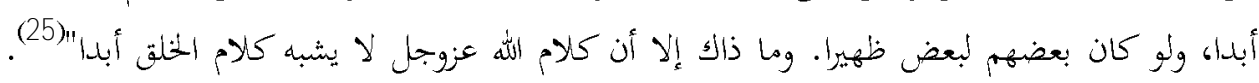

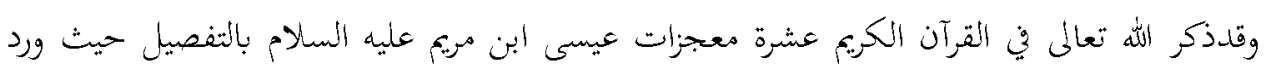

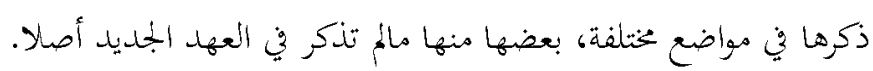

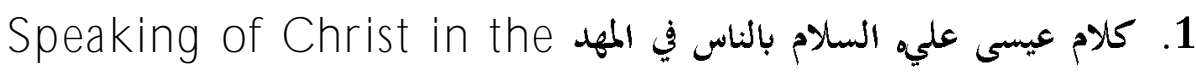

\section{C ot:}

هذه المعجزة الباهرة ذكرت في القرآن الكريع في ثلاثة مواضع، ولكن لمُ تذكر في العهد الجديد،

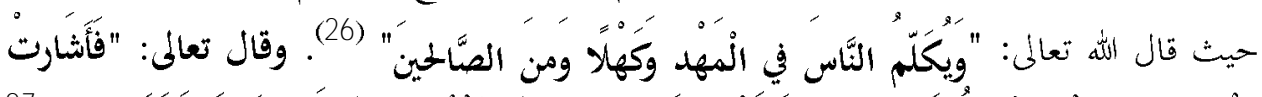

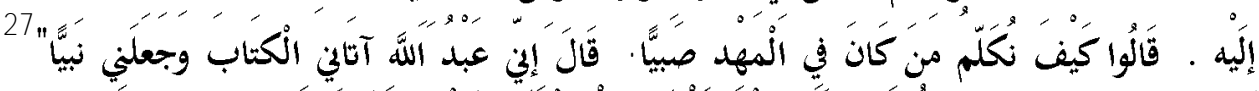

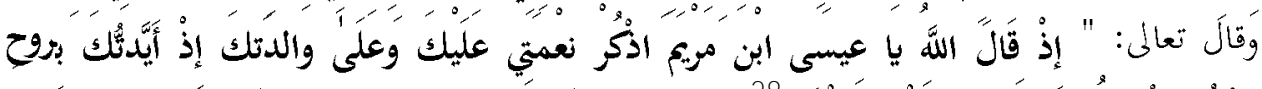

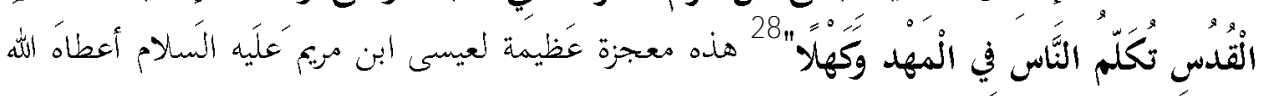

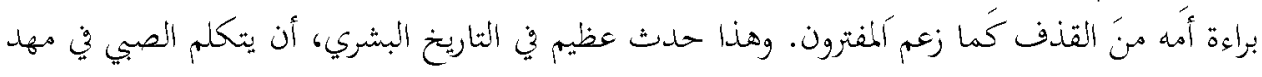


دى اسكالر (يوليو - ديسمبر 2017ء) معجزات المسيح التي ذكرت في القرآ (دراسة مقارنة) 57-77

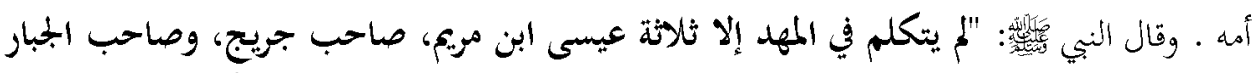

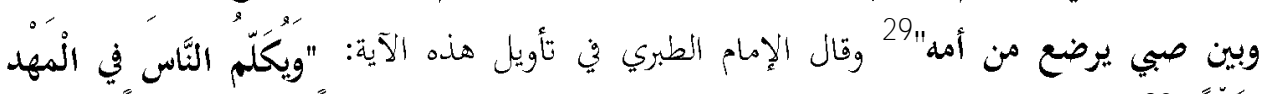

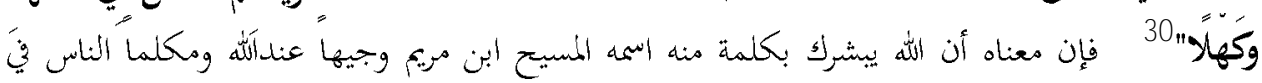
$31^{\prime \prime}$ وقال الحافظ ابن كثير: "أي يدعوا إلى عبادة الله وحلده لا شريك له في حال صغره معجزة وآية"(32).

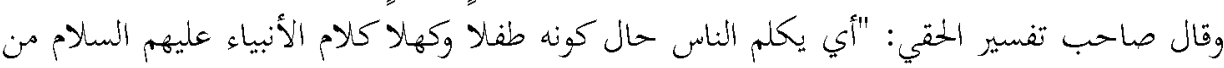

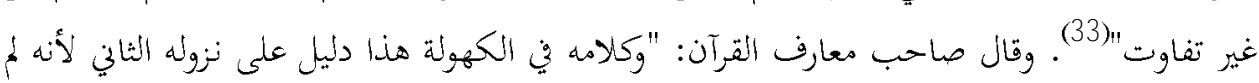

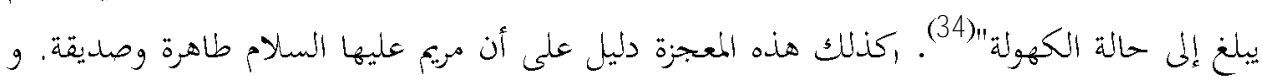

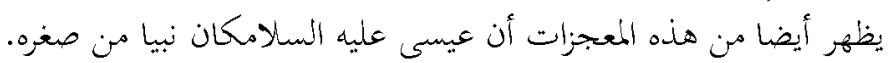

Making of B irds from M ud: 1 إن معجزة خلق الطير من الطين أيضا ذكرت فقط في القرآن الكريم ولم تذكر في العهد

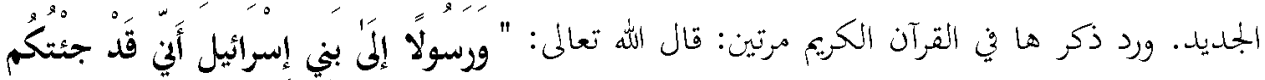

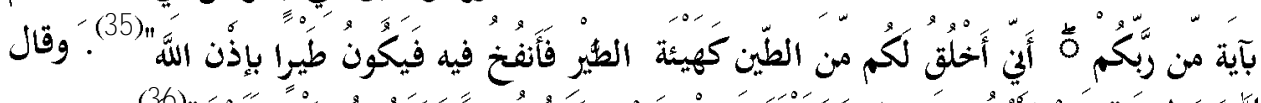

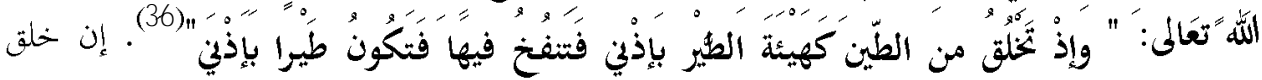

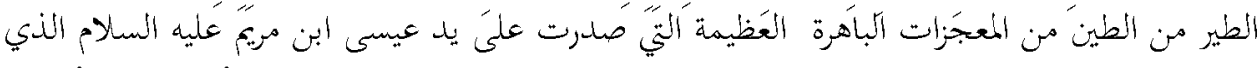

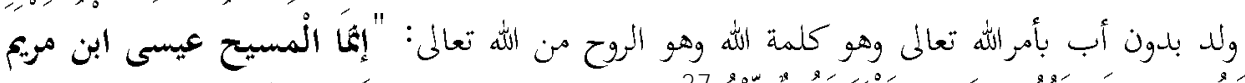

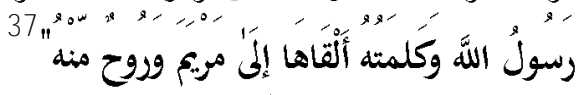

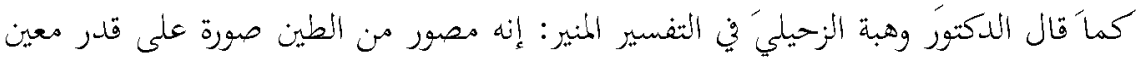

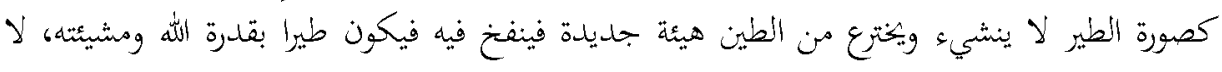

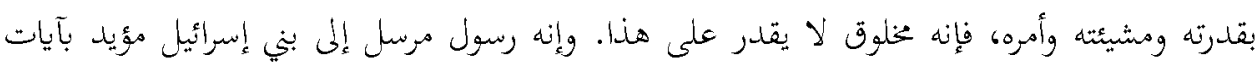
تدل على صدق رسالثه."38 و قال ابن كثير: "وكذلك كان يفعل: يصور من الطين شكل طير ثم ينفخ فيه فيطير عيانا بإذن الله عزوجل، الذي جعل هذا معجزة يدل على أن الله أرسله"

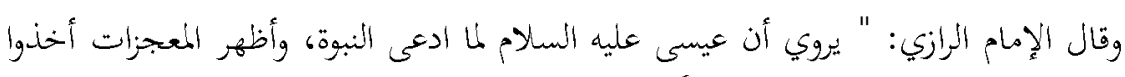

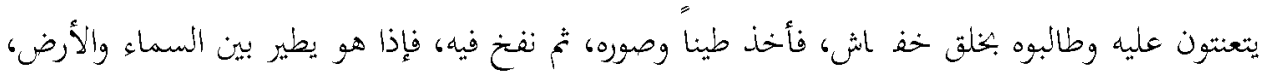

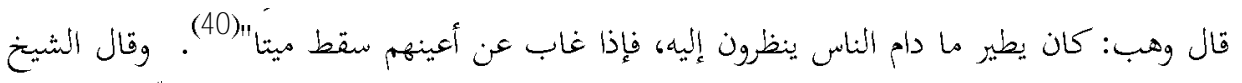
مُعَّمَ أبوزهرة: " أنه يصور من الطين كهيئة الطير فينفخ فيها فتكون طيرا بإِذن الله تعالى أي أنّ الله سبحانه 
دى اسكالر (يوليو - ديسمبر 2017ء) معجزات المسيح التي ذكرت في القرآن (دراسة مقارنة) 57-77

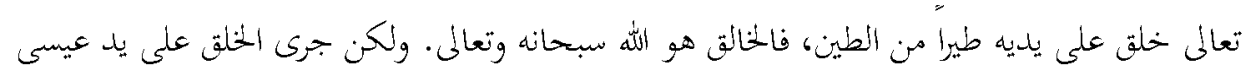
عليه الدلام وينفخ من روحه بإذن الله تعلالى"

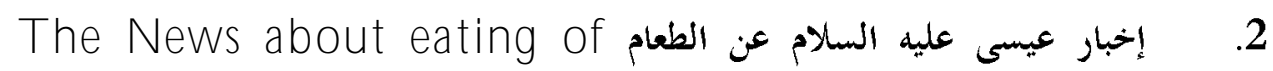

\section{Food:}

معجزة "الإخبار عن الطعام في البيوت" من المعجزات التي لم توجد في كتاب الإنجيل، ولكنن

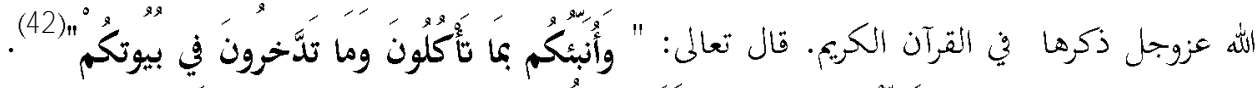

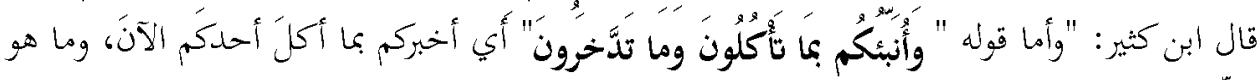
مأخر له في بيته لغده".

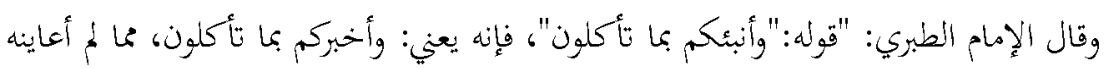

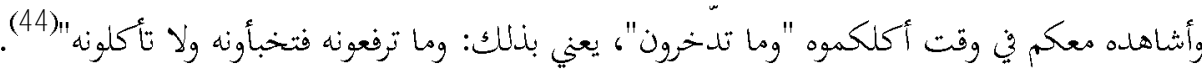

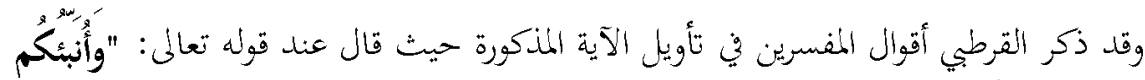

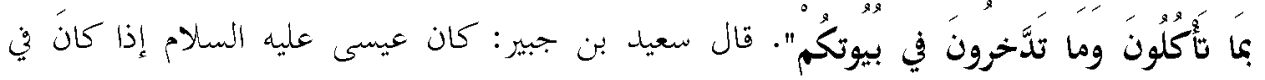

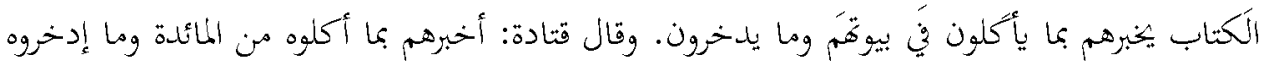

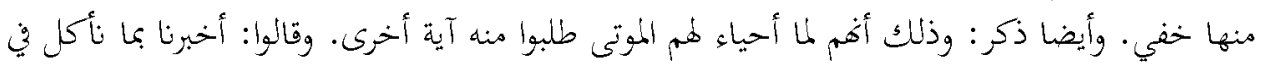

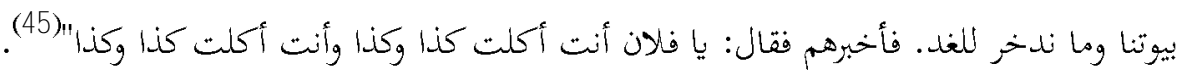

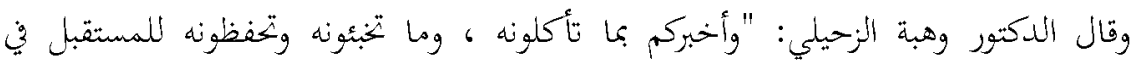

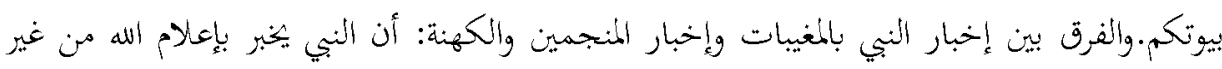

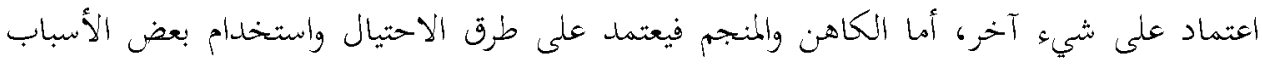

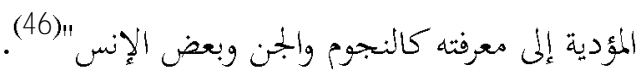

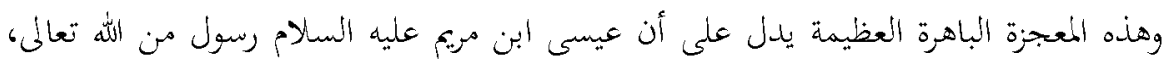

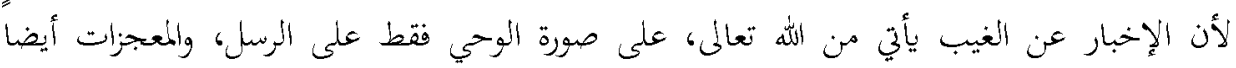

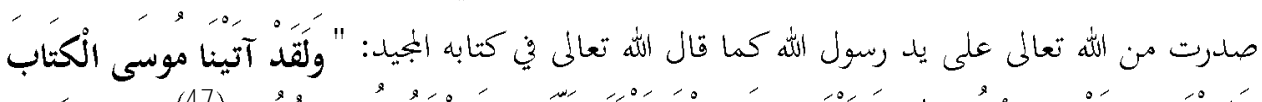

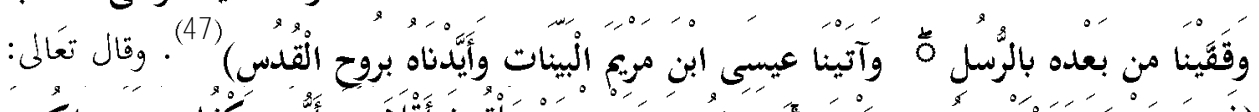

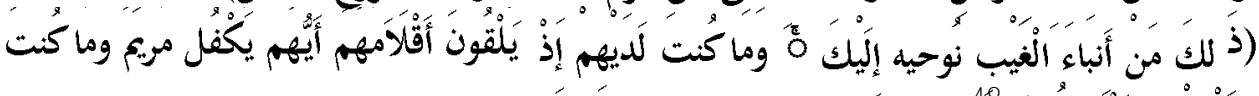

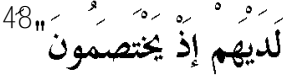

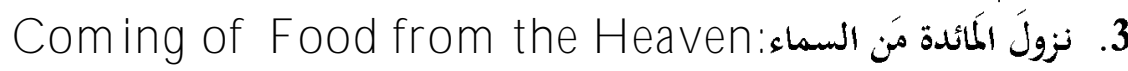

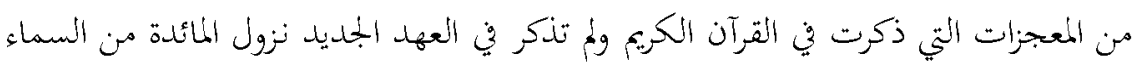


دى اسكالر (يوليو - ديسمبر 2017ء) معجزات المسيح التي ذكرت في القرآن (دراسة مقارنة) 57-77

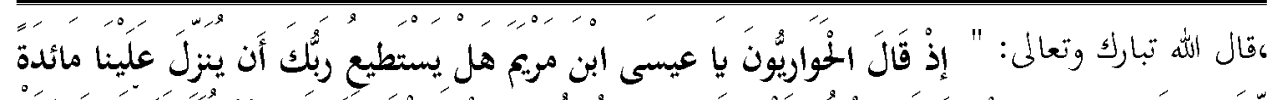

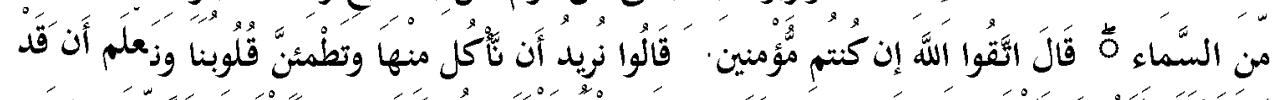

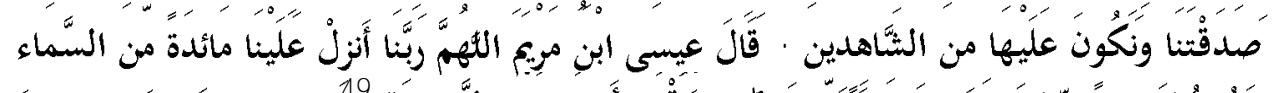

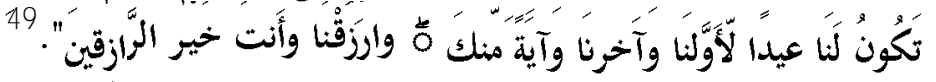

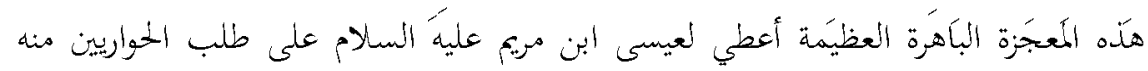

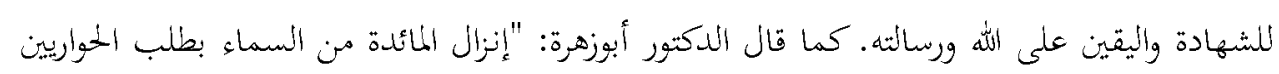
لتطمئن قلوبكم وليعلموا أن قد صدقهم". وقال ابن كثير: "هذه ق صة المائدة وإليها تنسب السورة فيقال: سورة المائدة وهي منا امتن الله

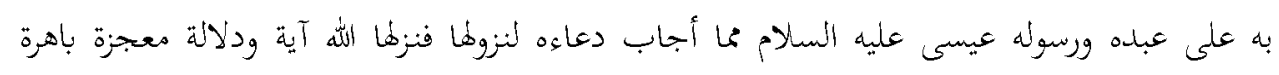

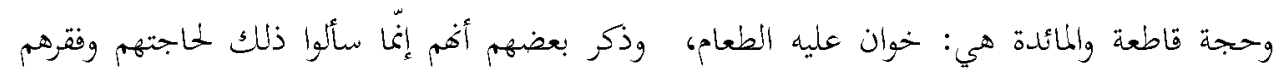

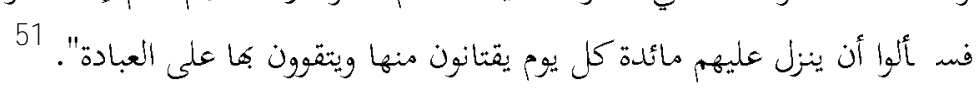

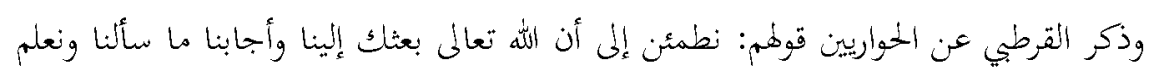

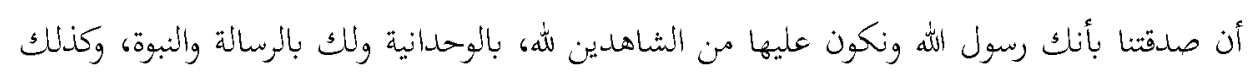
لك عند من لم يرها إذا رجعنا إليهم"

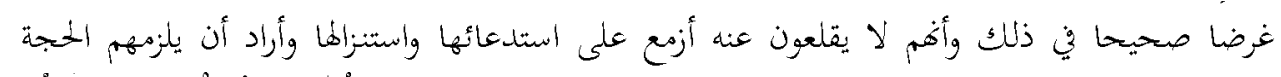

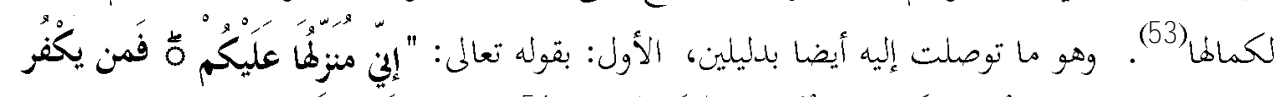

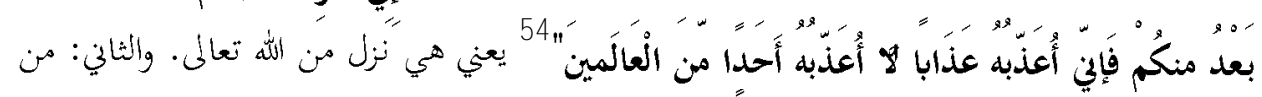

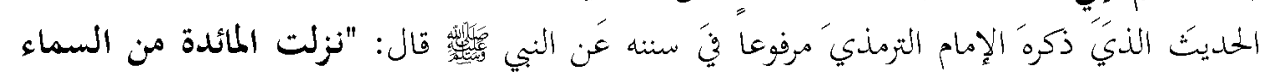

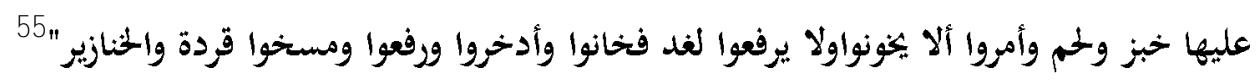

4. وقايته الله تعلى من كيد اليهود: Saving of C hrist from the Jews

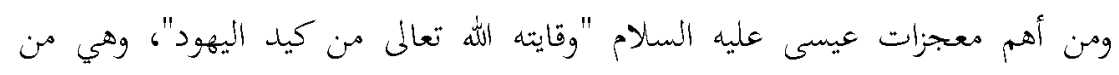

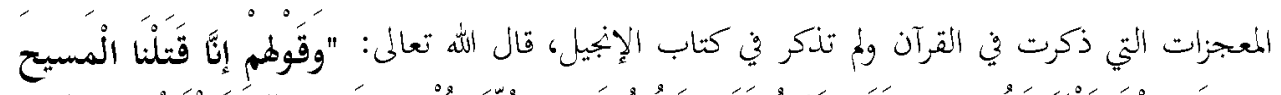

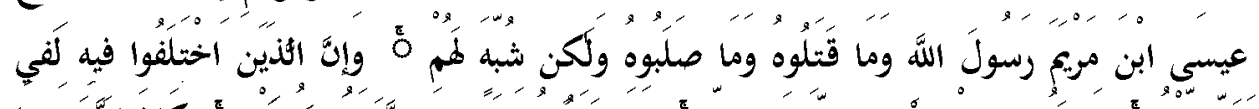

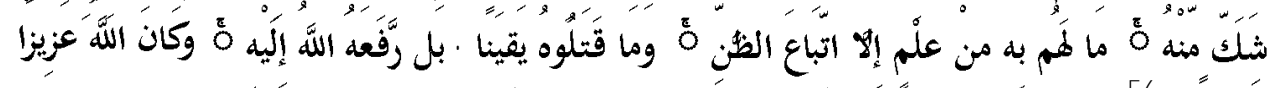

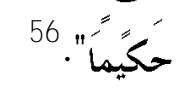
لم تذكر هذه المعجزة العظيمة في العهالجلديد ورفضها أيضاً عنها اليهود والنصارى كلاهما،

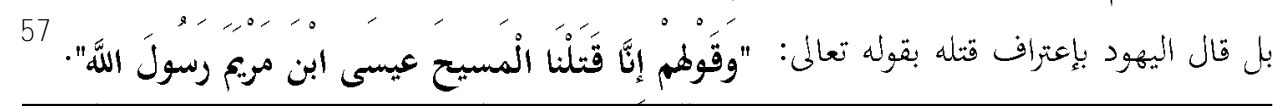


دى اسكالر (يوليو - ديسمبر 2017ء) معجزات المسيح التي ذكرت في القرآن (دراسة مقارنة) 57-77

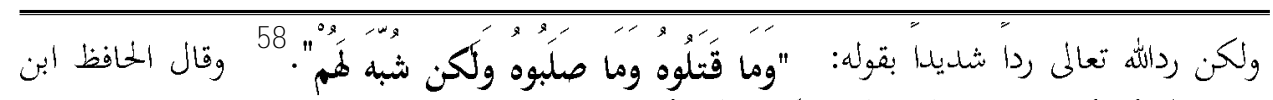

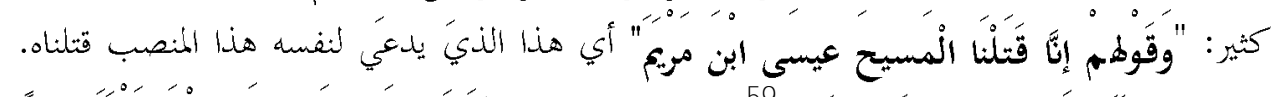

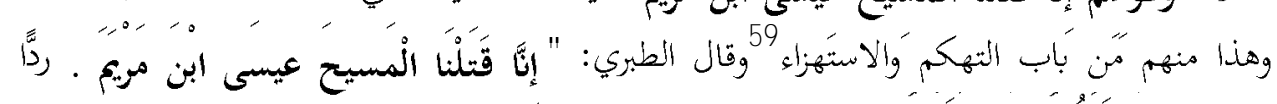

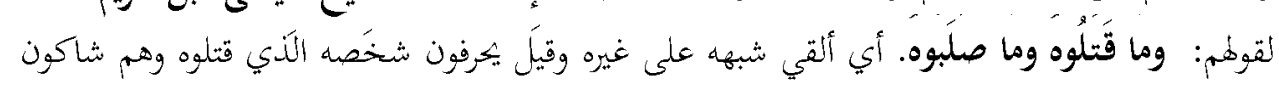

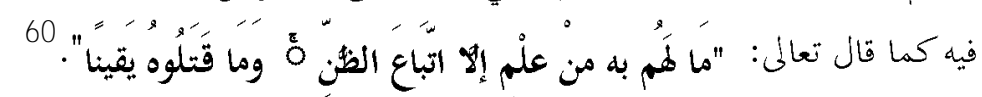

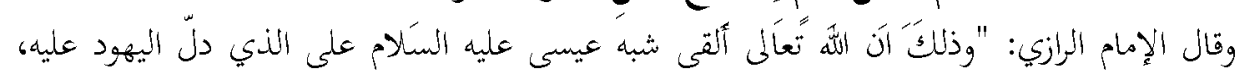

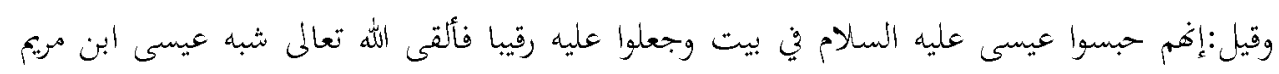

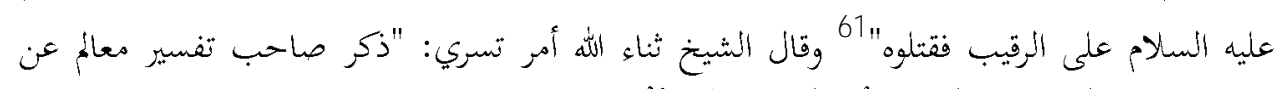

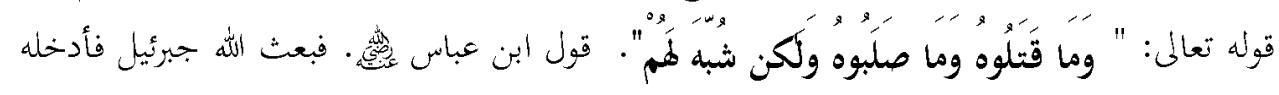

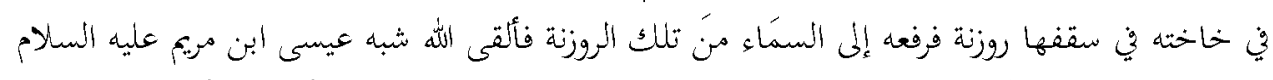

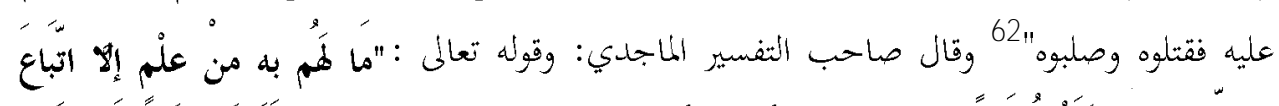

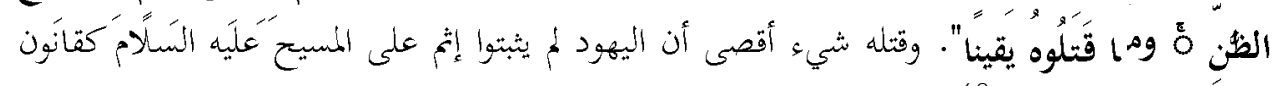

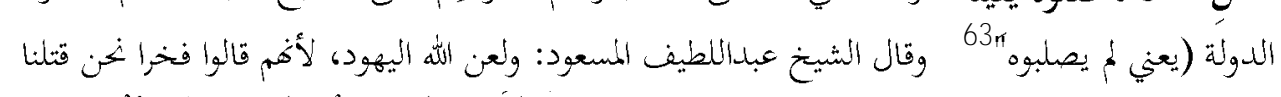

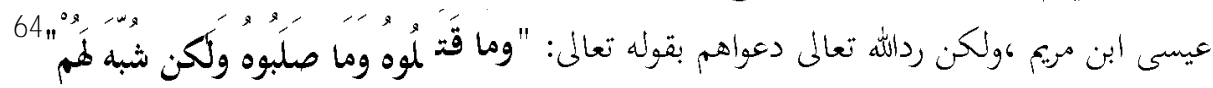

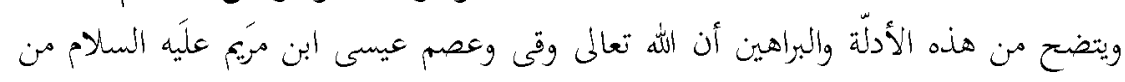

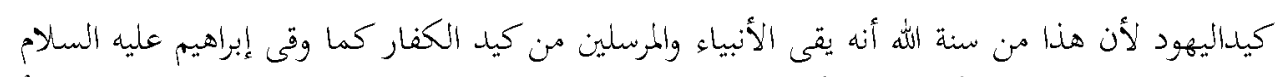

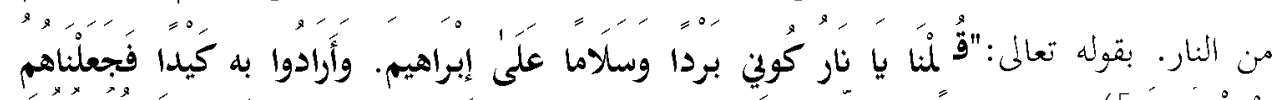

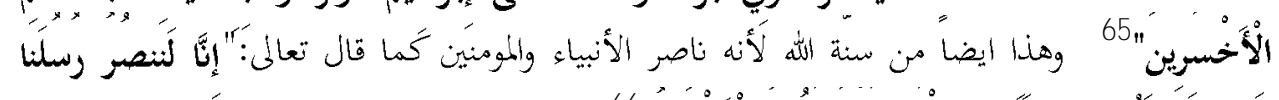

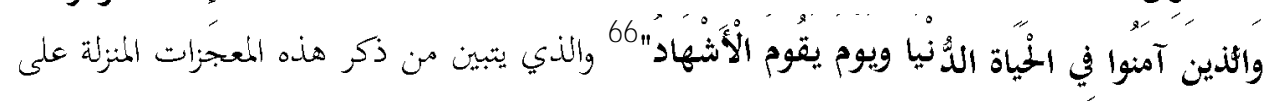

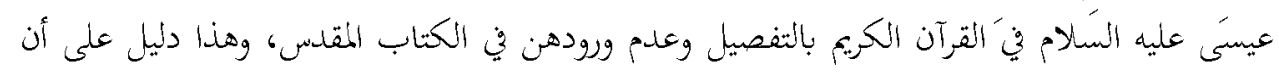

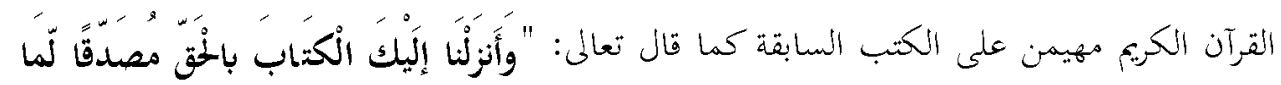

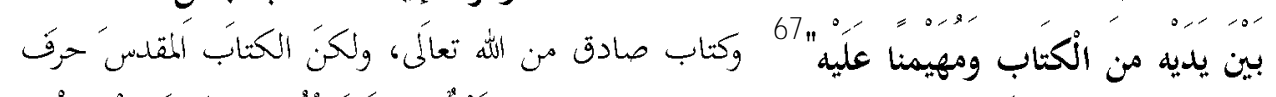

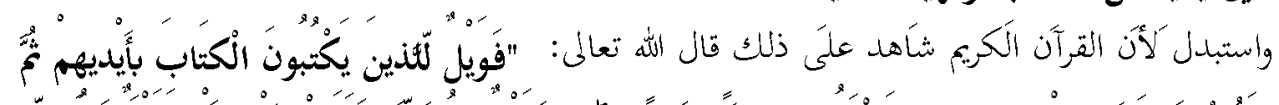

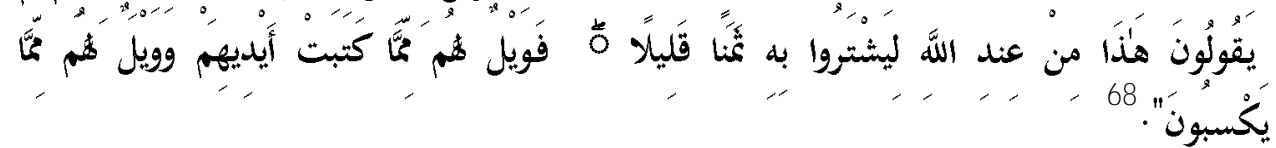
وإِمال كتاب الأناجيل المعجزات التي لم تذكر في الكتاب المقادس أيضا دليل على تحريفه،

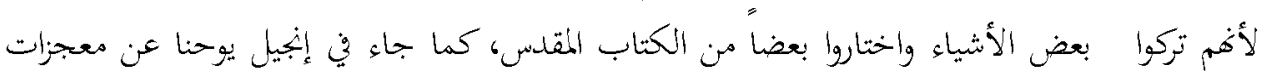


دى اسكالر (يوليو - ديسمبر 2017ء) معجزات المسيح التي ذكرت في القرآن (دراسة مقارنة) 57-77

عيسى عليه السلام: "وآيات أخرى كثيرة صنع يسوع قدام تلاميذه لم تكتب في هذا الكتاب. وأما هذه لفه

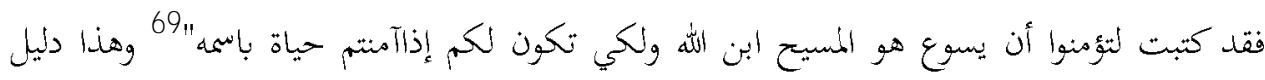

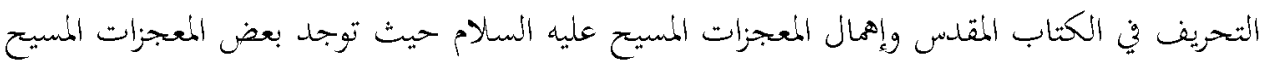
عليه السلام التي ذكرت في القرآن الكريم في الأناجيل الطفولة (The G ospels of Infancy)

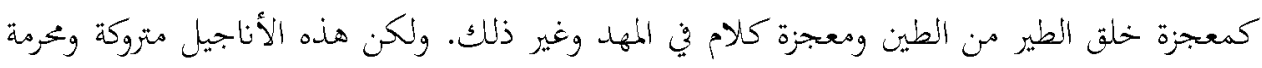

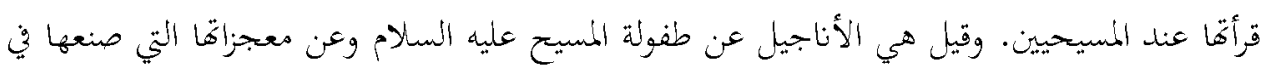

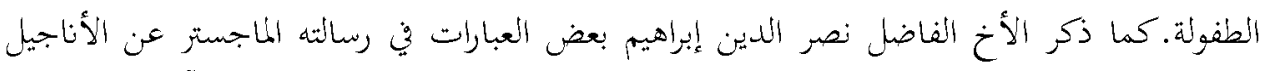

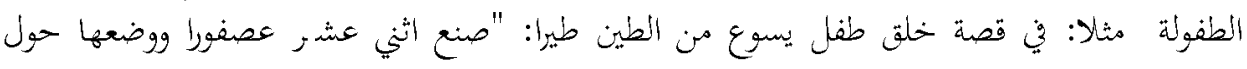
حفرته وعند صعق الرب يسوع بيديه على العصافير التي صنعها من الطين طارت العصافير مفردة" (70).

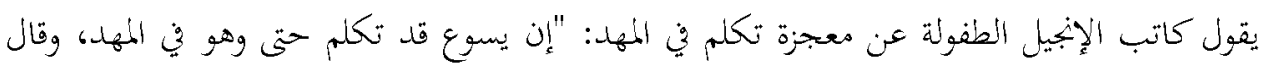

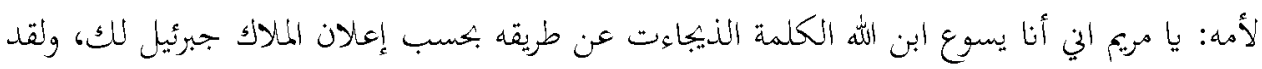

$$
\text { أرسلني أبي لخلاص العالم". } 71
$$

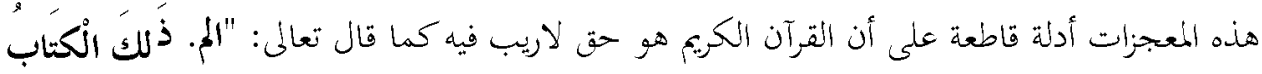

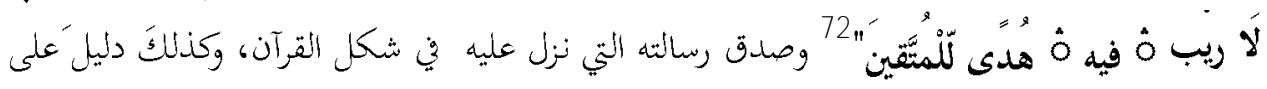

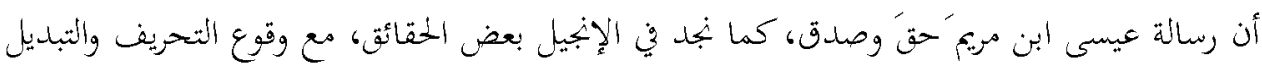

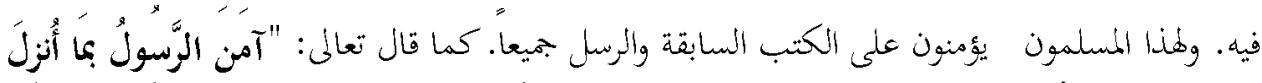

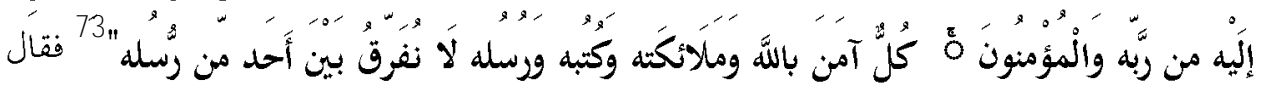

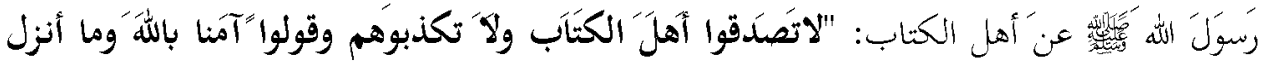

دراسة بين أراء علماء المسلمين والنصارى

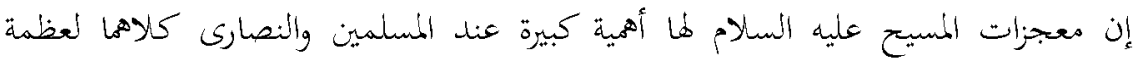
مكانته في الإسلام والمسيحية، لهذا السبب العلماء المسلمون والنصارى حاولوا، وفتشوا وكتبوا مواد كثيرة

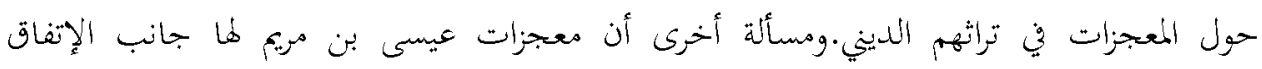

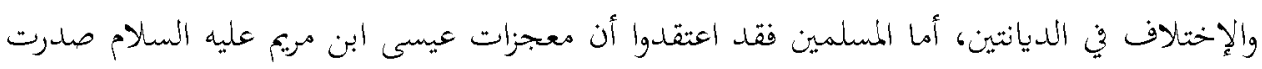

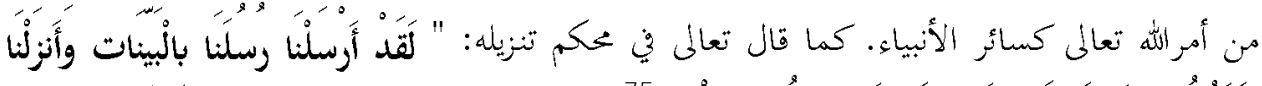

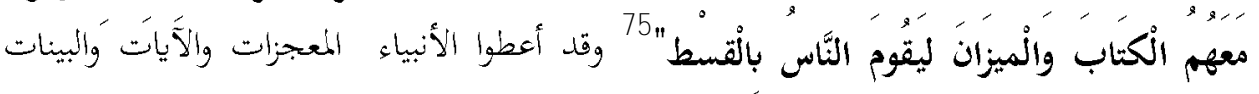

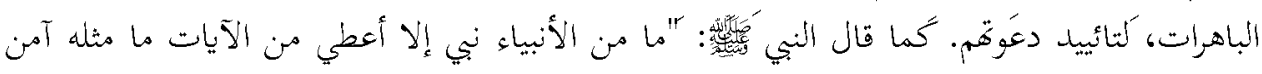




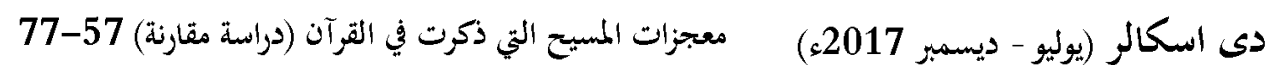

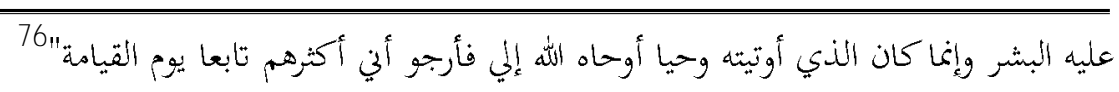

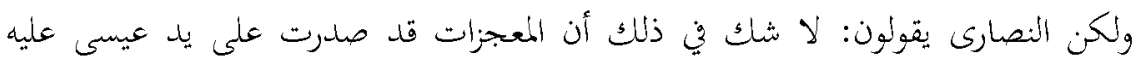

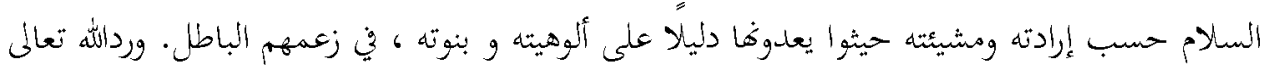

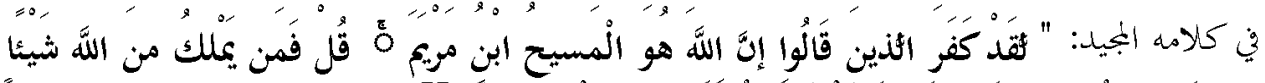

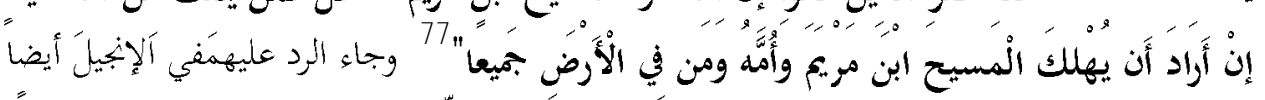

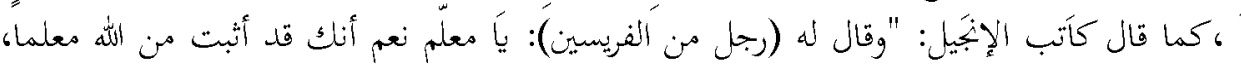

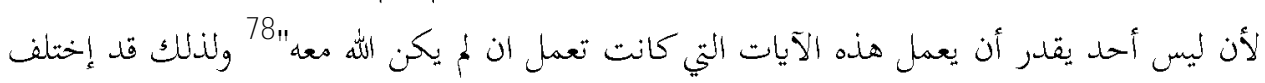

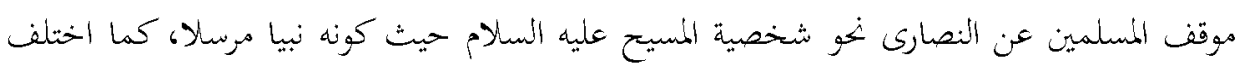

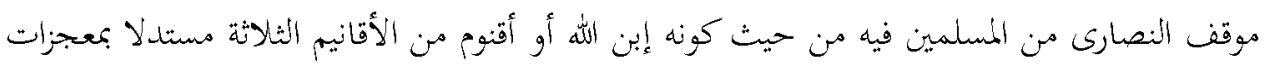

$$
\text { التي صدرت عن المسبح عليه السلام. }
$$

موقف علماء المسلمين عن المعجزات التي ذكرت في العهدالجديد:

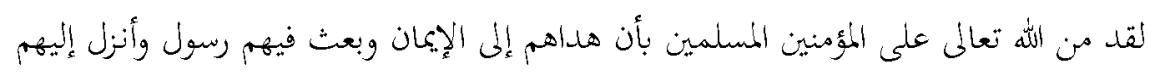

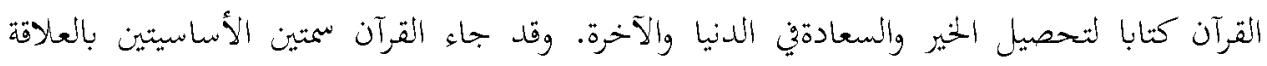

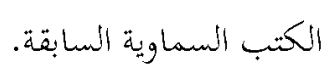

أولاً: القران مصدقا على الكتب السماوية السابقة وليس مغالفا للحقائق الرسالة السابقة كما قال

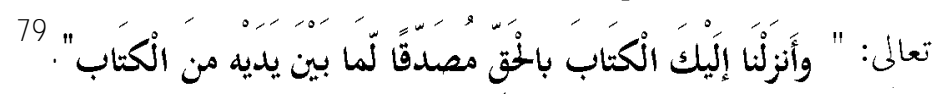

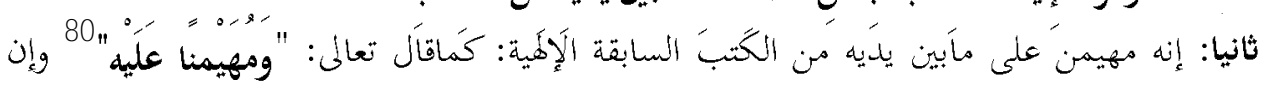

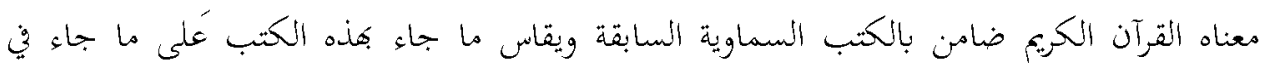

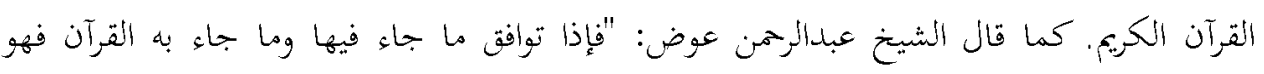
صحيح ونكتفي بالقران (81).

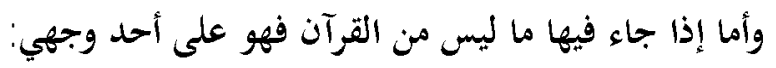

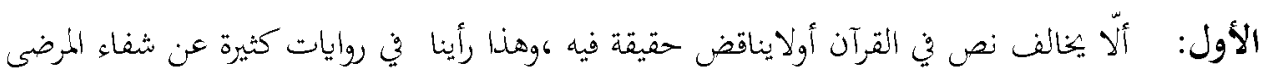

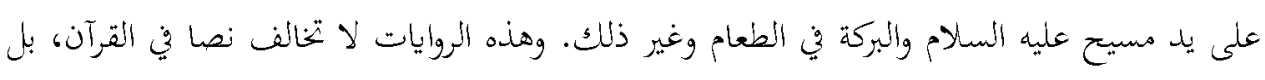

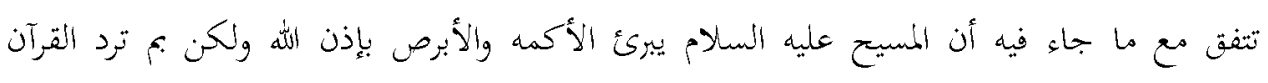

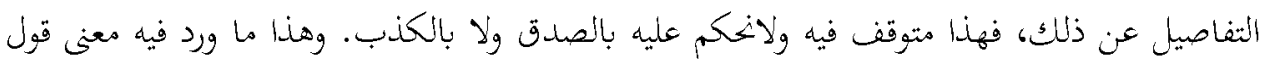

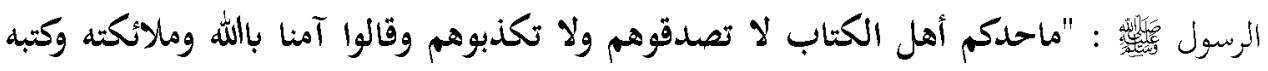

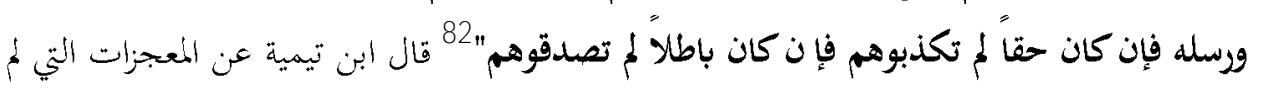


دى اسكالر (يوليو - ديسمبر 2017ء) معجزات المسيح التي ذكرت في القرآ (دراسة مقارنة) 57-77

تذكر في القرآن الكريم: "ومما يهكونه عن معجزة المسيح عليه السلام من المعجزات في حيز الإمكان؛ لا

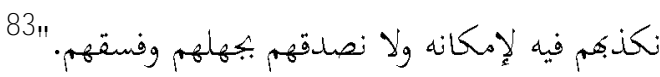

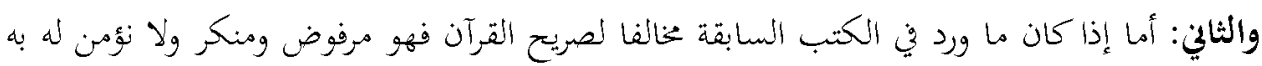

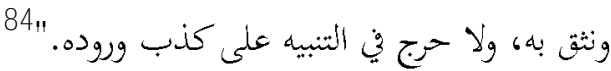

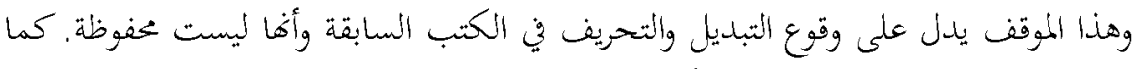

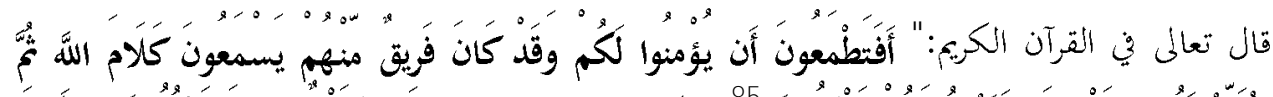

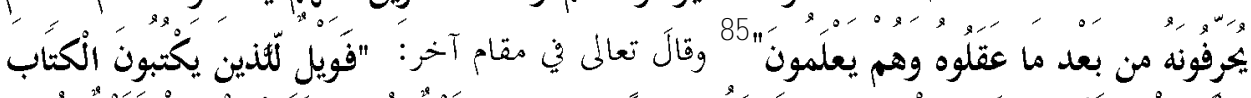

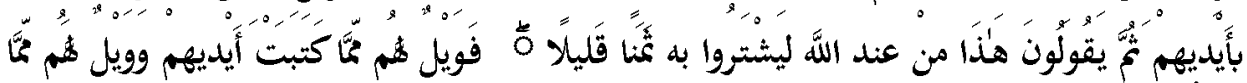

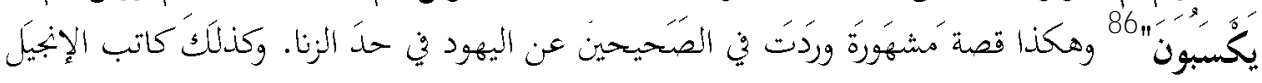

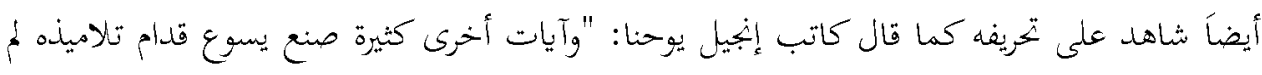

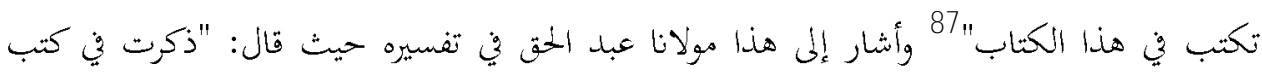

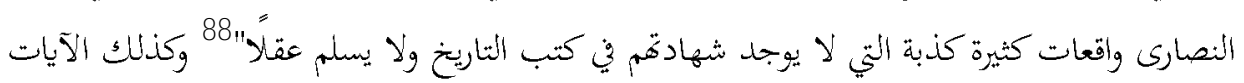

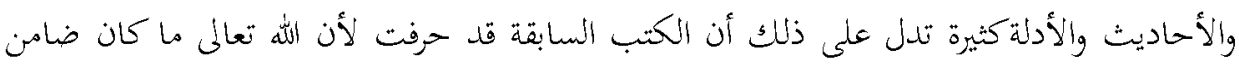

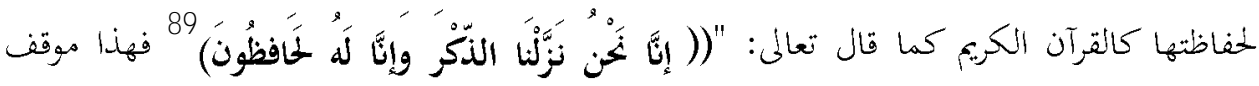

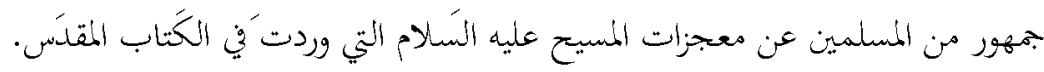

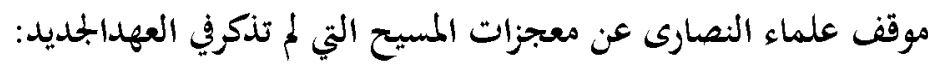

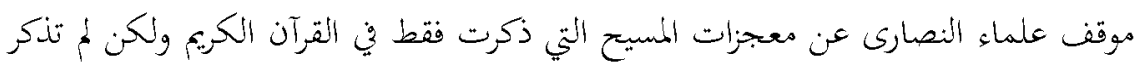
في الكتاب المقدس كلهم في هذه المسئلة رأيان: الأول: هم يؤمنون على هذه المعجزات التي ذكرت في القرآن الكريم والكتاب المقاس، ويقدموفا كدليل فضيلة عيسى ابن مريم عليه السلام التي جاء في القرآن الكريم، وهذه ناحية الإتفاق بين المسلمين

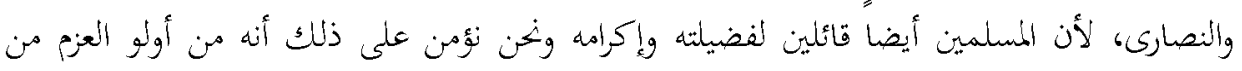

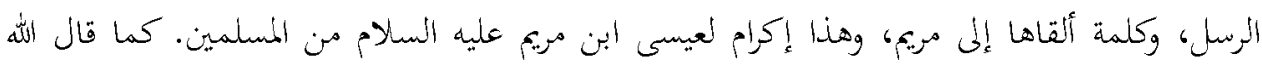

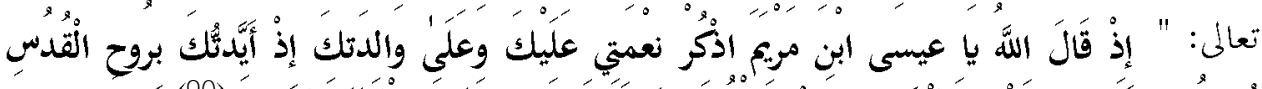

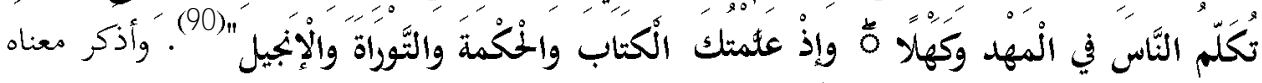

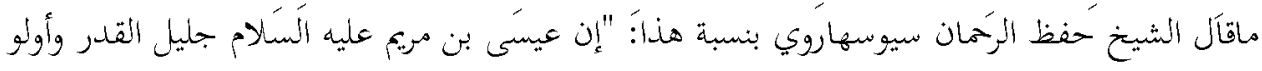

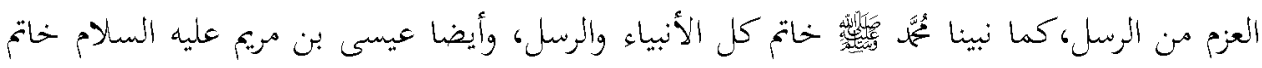

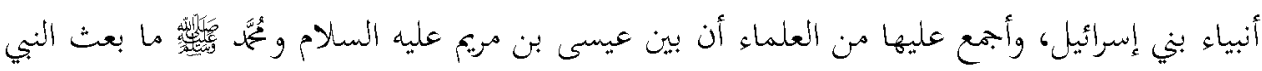


دى اسكالر (يوليو - ديسمبر 2017ء) معجزات المسيح التي ذكرت في القرآن (دراسة مقارنة) 57-77 هن الله تعلى ويقال هذه الفترة إنقطاع النبوة". 91 وهذه هي الحقيقة أن علماء النصارى يستدلون من هذه إنهوه المعجزات القرآنية فضيلة عيسى

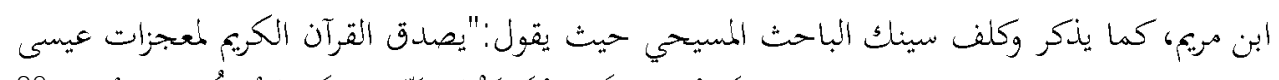

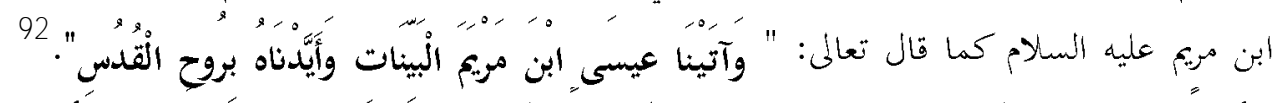

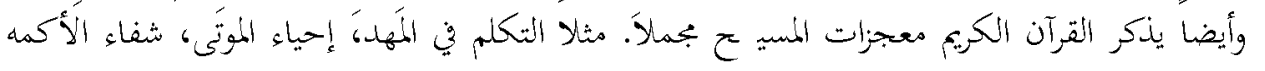

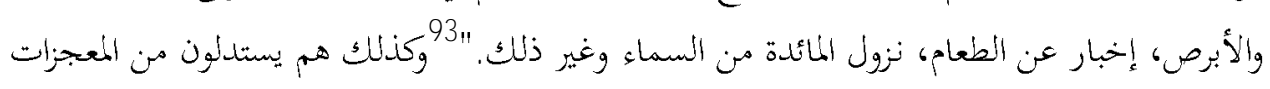

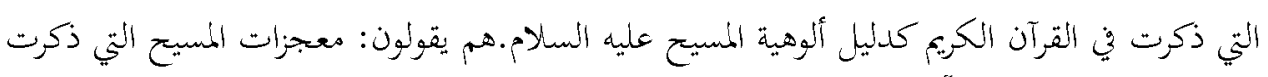

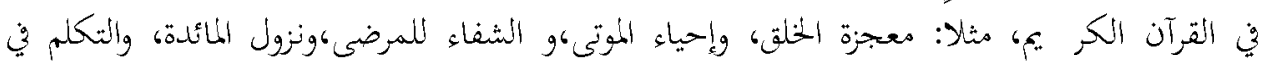

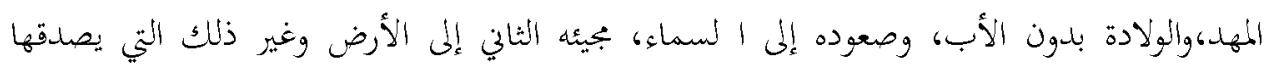

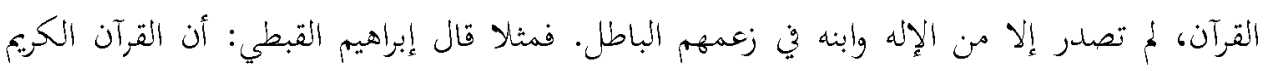

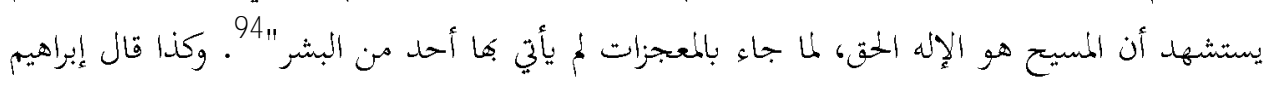

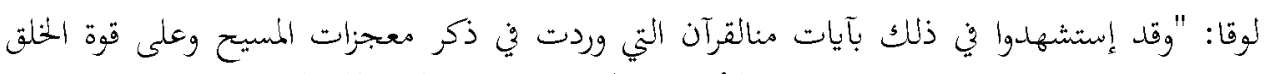

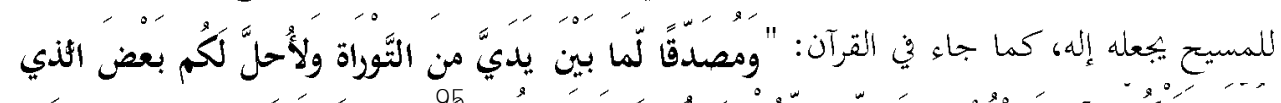

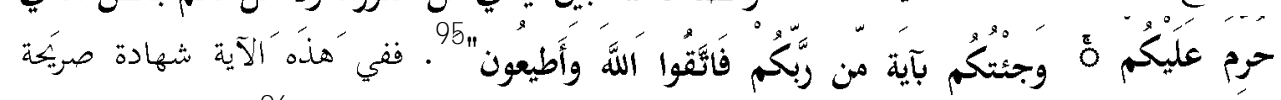

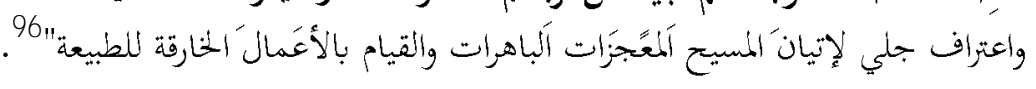

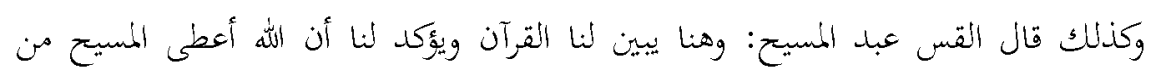

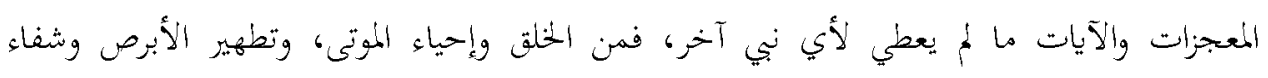

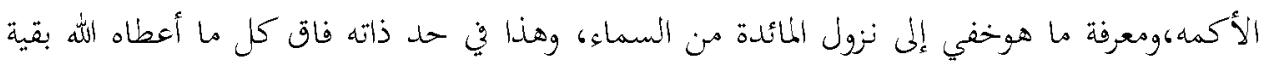

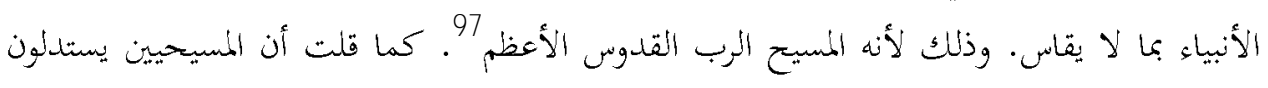

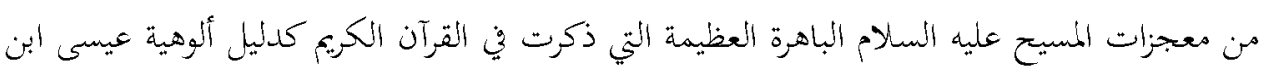

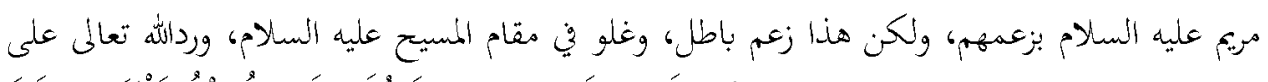

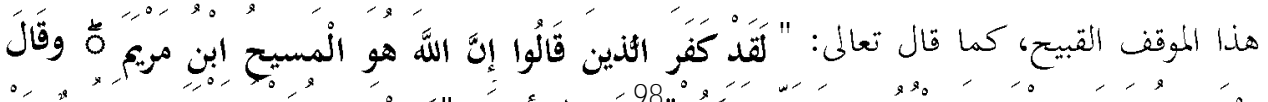

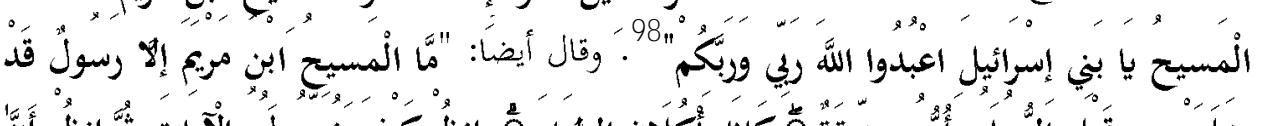

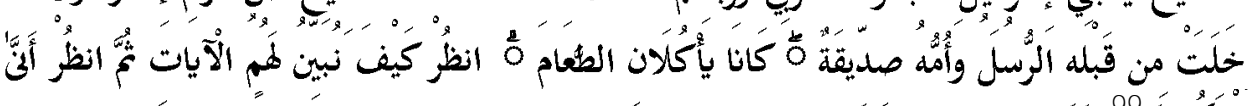

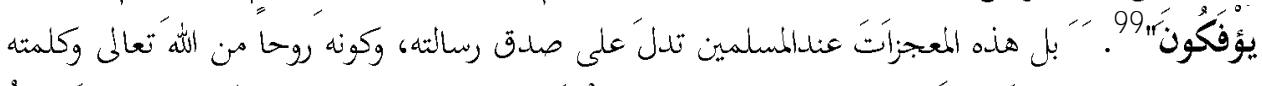

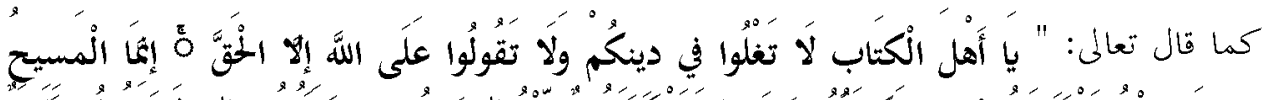

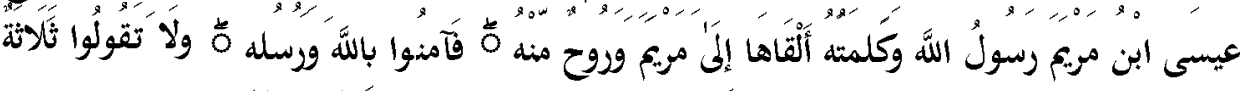




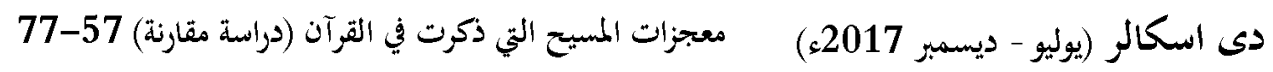

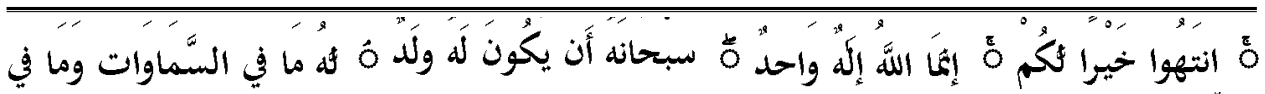

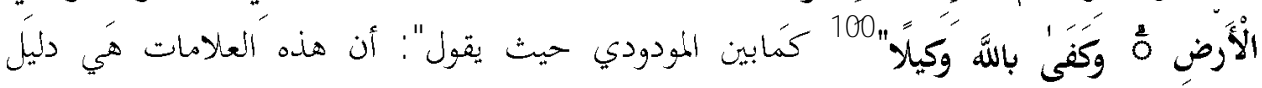

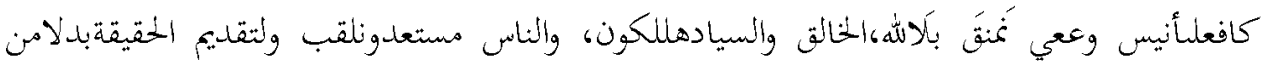

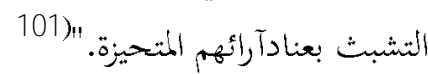

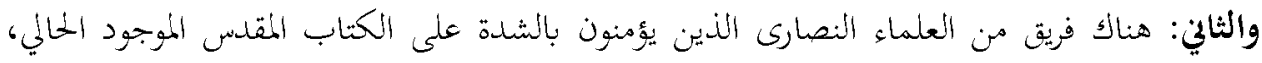

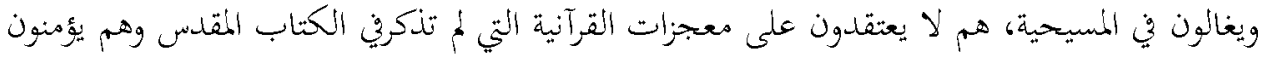

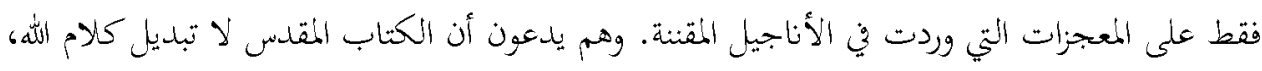

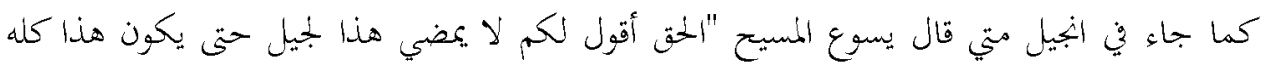

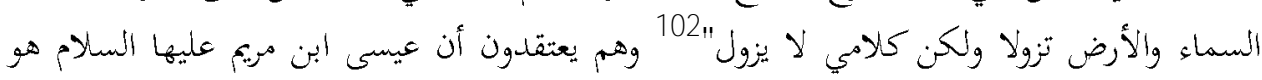

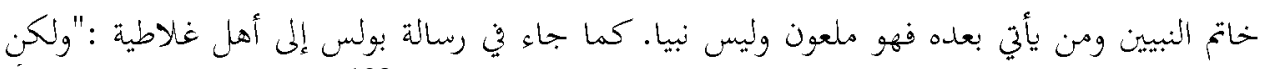

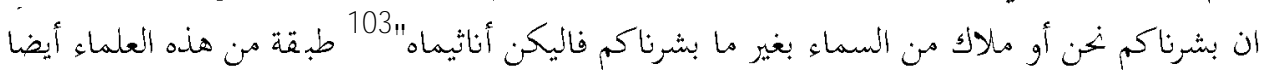

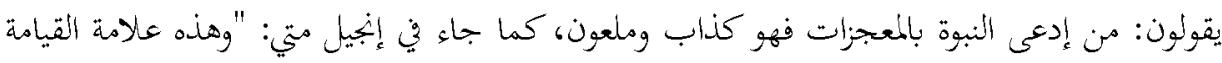

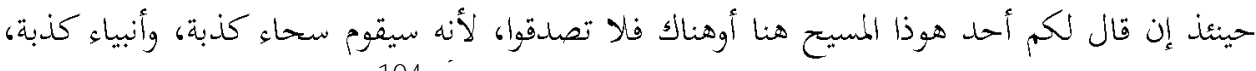

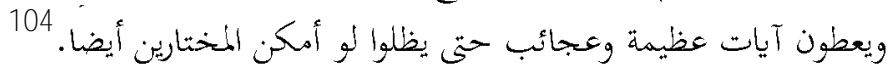

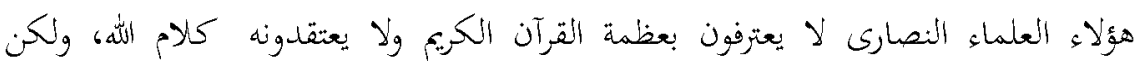

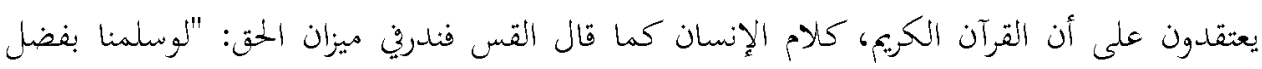

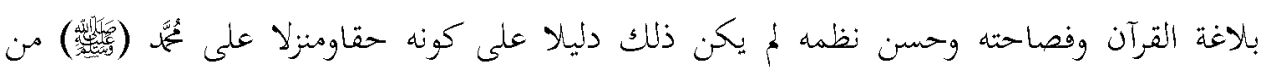
عندالة". 105

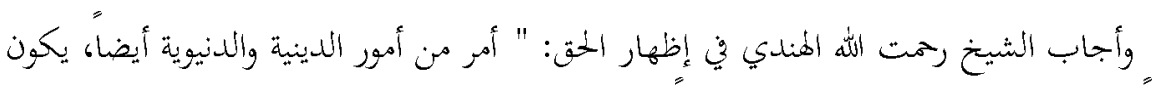

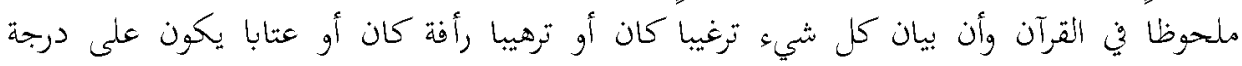

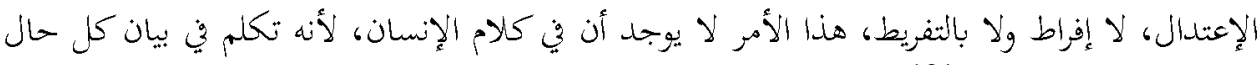

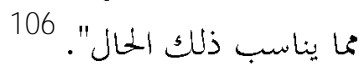

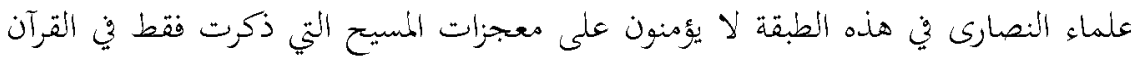

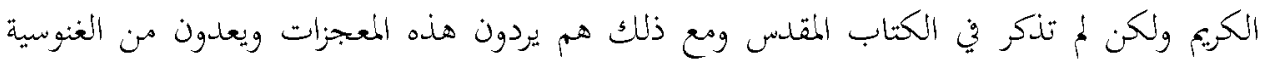

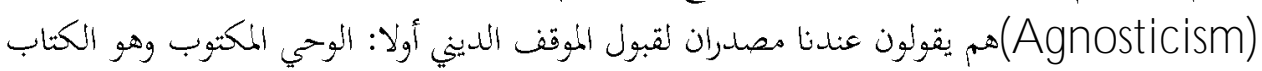

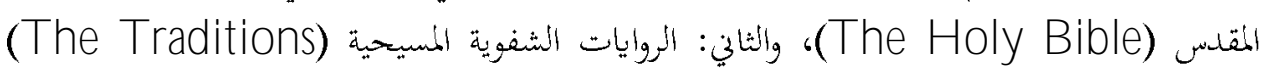

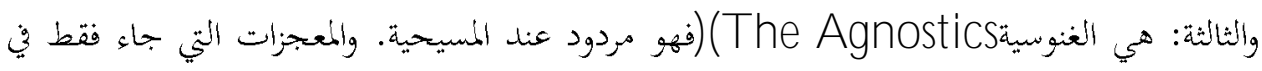

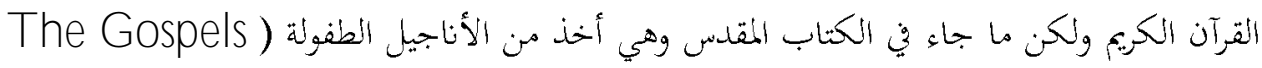
(The A pocrypha) وهي من الغنوسية، ولهذا هم لا يؤمنون على (of Infancy 


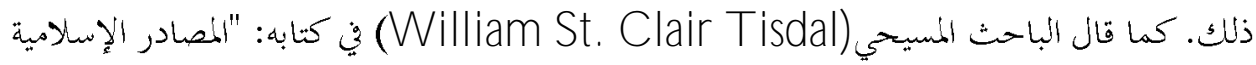
(The Sources of Islam)

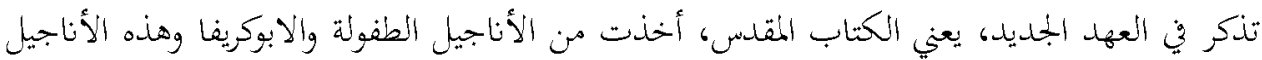

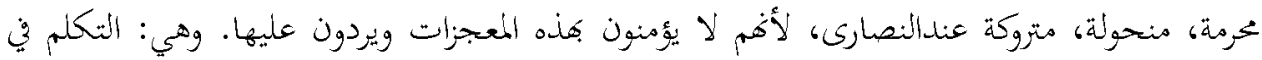

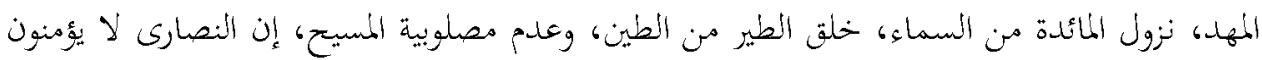

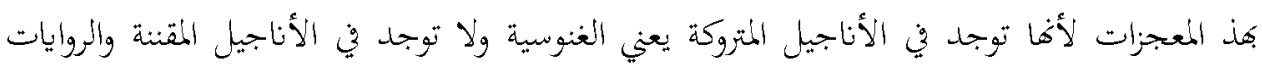
107ıI

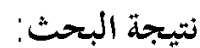

وفي فاية البحث وصلنا إلى هذه النتيجة أن معجزات المسيح عليه السلام ها أهمية كبيرة

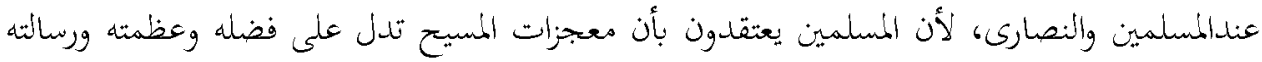

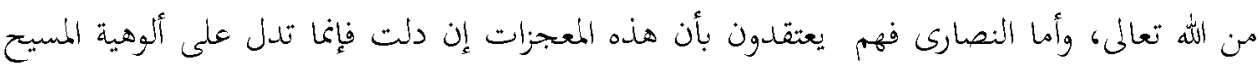

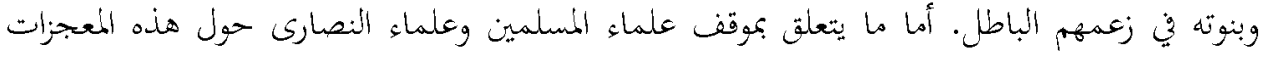

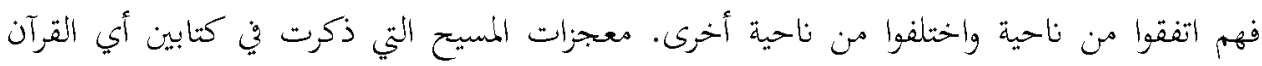

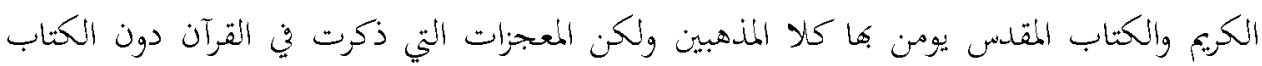

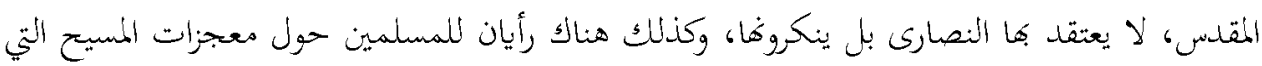

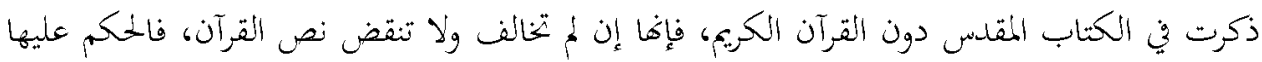

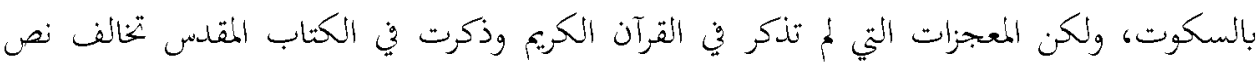

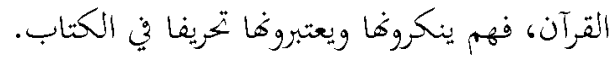

\section{(c) (1)(2)(2)}

Attribution-NonCommercial-ShareAlike 4.0 International (CC BY-NC-SA 4.0)

المراجع والمواشى

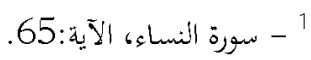

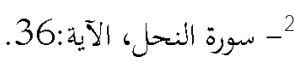

3- قشيرى، مسلم بن الحخاج، صحيح مسلم، كتاب الفضائل ، فضائل سيدنا عيسى ، دار السلام, الزياض 1999م 


$$
\begin{aligned}
& \text { كرقم } 4362 \text {. } \\
& \text { 4- سورة الغافر، الآية:53. }
\end{aligned}
$$

5 - ابن تيمية ، تقي الدين أممد بن عبد الحليم، النبوات، المملكة العربية السعودية، الرياض،2000 م،ص 28.

$$
\text { 6- سورة التوبة ، الآية:30. سورة آل عمران،الآية:49. }
$$

8- سعيدي، غلام رسول، تبيان القرآن، فريد بك ستال ، لاهور، 2009، ج,2ص176.

9- سورة البقرة، الآية:23.

10- البخاري ، يُجّهُ بن إنماعيل،انصحيح البخاري، كتاب الإعتصام بالكتاب والسنة ، باب بعثت بهوامع الكلم، ، دار

$$
\text { السلام، الرياض ,1999 رقم } 6846 .
$$

11 - الكتاب المقدس :يكتوي الكتاب المقدس قسمبن، واحد هو العهد القدنيم الذي هو موثوف بها لليهود والآخر هو العهد الجديد الذي هو الحجية للمسيحيين. وتشرح هذه الدراسة معجزات العهد الجديد الذي هو الكتاب المقدس

12 ابن منظور، مُمُّدّ بن مكرملسان العرب، دار إحياء النتراث العربي - بيروت، 1422هـ، ص:57-58.

$$
\text { 13 بجمع اللغة العربية،المعجم الوسيط، دار الدعوة، القاهرة, } 2010 \text { م ، ج2 ،ص585. }
$$

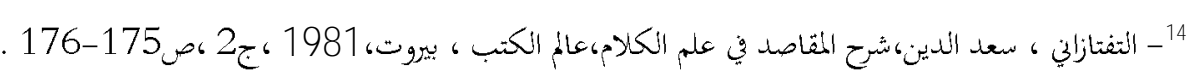

$$
\text { 15 - النبوات، المصدر السابق، ص9. }
$$

16- جرجاني، علي الزين الشريف، كتاب التعريفات،دار الكتب العلمية بيروت ،لبنان، 1983 م، ص282. 17- الآمدي، سيف الدين ،غاية المرام في علم الكلام، المجلس الأعلى للشئون الإسلامية ،القاهرة، 1391 ه،ص332.

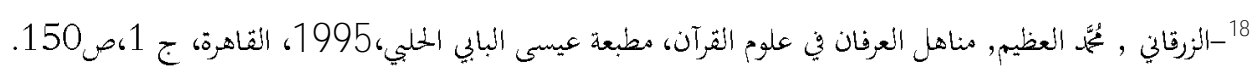
19-كوتس، دبليو . (مدير عام)، موسوعة بريتانيكا الجديدة، دبليو بي ناشر لندن، 1974 ج6،صو927. 20- موسوعة جديدة الكاثوليكية، المصدر السابق،ج9،ص890. 
21 - بيمس هيستك (مدير عام)،موسوعة الدين والأخلاق، كيسنجر ناشر، الولايات المتحدة

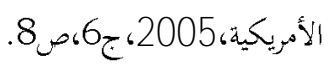

22 - القس طالب الدين، معجزات مسيح، بنجاب رليجيس بك موسائتي -لاهور طبع دوم 1957م ، ص11 -12.

$$
\text { 23 } 23 \text { سورة المائدة، الآية:48. سورة الغافر، الآية:28. }
$$

25- ابن كثير، أبو الفداء إنماعيل بن عمر،قصص الانبياء، مطبعة دار التأليف ،القاهرة، 1968م، ص513.

$$
\begin{aligned}
& \text { 26-سورة آل عمران،الآية:46. } \\
& \text { 27 سورة مريم ، الآية:29-30. } \\
& 28 \text { 20سورة المائدة،الآية:110. }
\end{aligned}
$$

29-صحيح مسلم ، كتاب البر، باب تقديم بر الوالدين ,رقم 254.

$$
\text { 30 - سورة آل عمران، الآية:46. }
$$

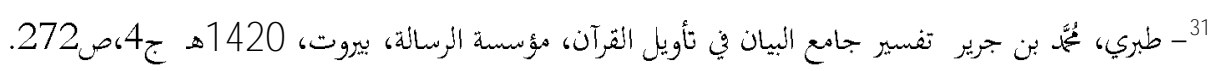

32 ابن كثير، أبو الفداء إنماعيل بن عمر،تفسير القرآن العظيم ، دار الكتب العلمية، بيروت 1419 هـ،

$$
.3740 .4
$$

33 - الحقي ،شيخ إنماعيل ، تفسير روح البيان، دار إحياء التراث العربي ، بيروت، 2001م، ج2،28.

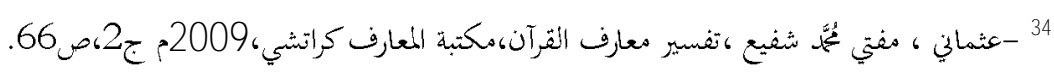

$$
\text { - سورة آل عمران، الآية:49. }
$$

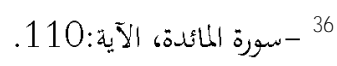

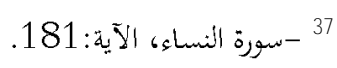

38-الزحيلي، وهبة بن مصطفى، التفسير المنير، دار الفكر المعاصر ،دمشق،1418 هـ، ص232.

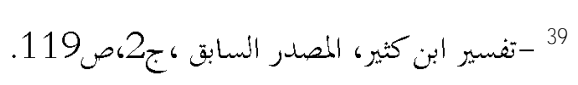


40 -رازي،فخر الدين ،تفسير الرازي،دار إحياء التراث العربي ، بيروت 1420 هـ ج7،ص51.

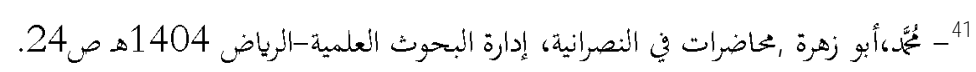

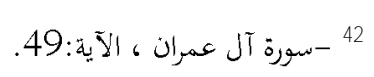

43 - تفسير ابن كثير ،المصدر السابق ،ج2،ص119. 44 تفسير الطبري، المصدرالسابق، ج3،ص277. 45 -القرطبي، شمس الدين ،تفسير القرطبي، دار الكتب المصرية - القاهرة 1964 م ج4،ص61. 46 -تفسير المنير،المصدر السابق ،ج3،ص233.

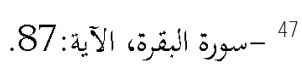

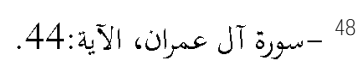
49 - سورة المائدة، الآية:112-115. 50 - محاضرات في النصرانية، المصدر السابق، ص25. 51 -تفسير ابن كثير، المصدر السابق، ج2،ص120. 52 53 تفسير الحفي،المصدر السابق ،ج2،ص125.

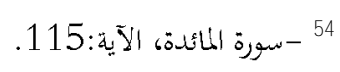

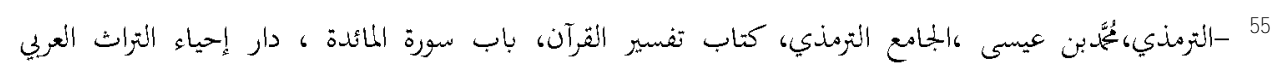
بيروت،2000م، ج5،ص260،رقم 3061. 56 -سورة النساء، الآية:157-158.

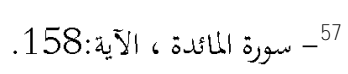

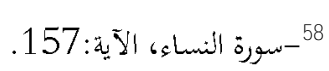
59 -تفسير ابن كثير، المصدر السابق، ج2،ص120. 


$$
\begin{aligned}
& 60 \text {-تفسير الطبري، المصدر السابق، ج4،ص65. } \\
& 61 \text {-تفسير الرازي، المصدر السابق ،ج7،ص51. } \\
& 62 \text {-أمرتسري ثناء الله، تفسير ثنائي، مكتبه اصحاب الحديث ،لاهور، 2007م، ص244. } \\
& 63 \text { - دريا آبادي، عبدالماجد،تفسير الماجدي، طبع اول، تاج كمبني ،كراتشي، 1952م، ج1ص227. } \\
& 64 \text {-مسعود شيخ عبدالنطيف،مسئله رفع ونزول المسيح، علمي بجلس ختم نبوت ،ملتان، 1997م، ص184. } \\
& \text { 65 -سورة الأنبياء ، الآية:69-70. } \\
& \text { 66- سورة الغافر، الآية:51. }
\end{aligned}
$$

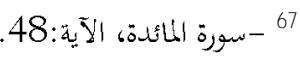

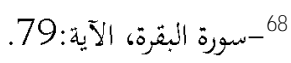

$$
\begin{aligned}
& \text { 69 - انجيل يوحنا، 20: 30-31. }
\end{aligned}
$$

70-إبراهيم، نصر الدين ، معجزات المسيح بين الإنجيل والقرآن ، رسالة ماجستير، الجامعة الإسلامية العالمية ،اسلام

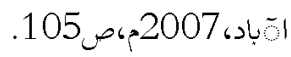

3-1: 1 - 1 - انجيل الطفولة

-

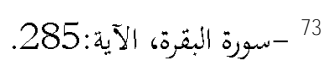

74 -انصحيح البخاري، كتاب التفسير، باب قولوا آمنا بالله وما أنزل إلينا،رقم 4215.

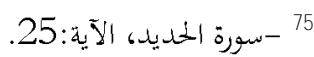

76-الصحيح البخاري، كتاب الإعتصام بالكتاب والسنة ، باب بعت بجوامع الكلم ، رقم: 6846.

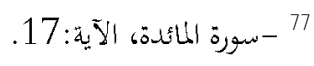

$$
\text { 30:38 - انجيل يوحنا } 20
$$

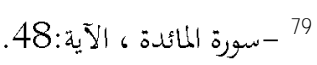


81 -عبدالرمن عوض، معجزات المسيح في الإنجيل والقرآن، دار البشير القاهرة، الطبعة الاولى 1990م،ص 141. 82 -ابن حبان، بُمّمّ بن حبان ،صحيح ابن حبان، باب بدء الحلقل، مؤسسة الرسالة، بيروت، 1988

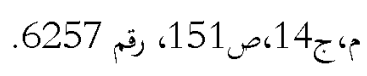

83 -ابن تيمية ، تقي الدين أحمد، إقتضاء الصراط المستقيه، دار عالم الكتب، بيروت، لبنان ،1999م، ص213.

$$
84 \text {-معجزات المسيح في الإِجيل والقرآن، المصدر السابق، ص124. }
$$

85

86

20:30 - 20:30

88 -حقائ، عبدالحق ,تفسير حقاني،مكتبه عزيزية ،لاهور، 1990م، ج1،ص115.

89

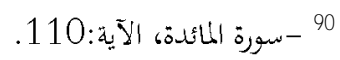

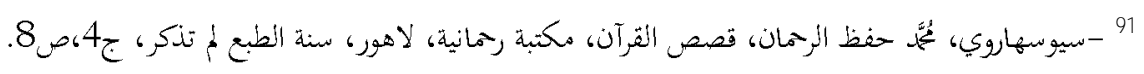

$$
92
$$

93 -وكلف سينك،فضيلة المسيح،مسيحى اشاعت خانه، لاهور، طبع دوم 1998م،ص، 61 -62. 94

$$
95
$$

96 - إبراهيم لوقا ،المسيحية في الإسلام، ص 26، 17/9/16/www .alkalima.net 97

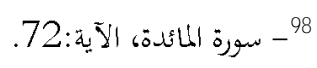

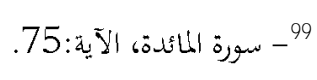


100 - سورة النساء، الآية:171.

101- مودودي، سيد أبو الاعلي، تفهيم القرآن، إدارة ترجمان القرآن ، لاهور، 2003م، ج1،ص253.

$$
\begin{aligned}
& \text { 102 - انجيل متي 24: } 35 . \\
& \text { 103-ـ رساله الىى غلاطية 1: } 8 . \\
& \text { 104 انجيل •تي 24: 23- } 24
\end{aligned}
$$

105 سي .جي .فيندر،ميزان الحق، بنجاب رئيجيس بك سوسائتي لاهور طبع دوم 1962 م،ج3، ص336. 106- الهندي ،رحمت الله، إظهار الحقى، إدارة البحوث العلمية،الرياض 1994ه، الجزء الثانث ،صب774. 107- تسدال ،وليم سانت كلير ، المصادر الإسلامية ، اماركو بك ايجنسي ، لندن، 1973م، ص 57-60. 